\title{
Changes in optical characteristics of surface microlayers hint to photochemically and microbially mediated DOM turnover in the upwelling region off the coast of Peru
}

\author{
Luisa Galgani ${ }^{1,2}$ and Anja Engel ${ }^{1}$ \\ ${ }^{1}$ GEOMAR - Helmholtz Centre for Ocean Research Kiel, Düsternbrooker Weg 20, 24105 Kiel, Germany \\ ${ }^{2}$ Alfred-Wegener-Institute - Helmholtz Centre for Polar and Marine Research, Am Handelshafen 12, \\ 27570 Bremerhaven, Germany
}

Correspondence to: Anja Engel (aengel@geomar.de)

Received: 16 November 2015 - Published in Biogeosciences Discuss.: 7 December 2015

Revised: 15 April 2016 - Accepted: 19 April 2016 - Published: 27 April 2016

\begin{abstract}
The coastal upwelling system off the coast of Peru is characterized by high biological activity and a pronounced subsurface oxygen minimum zone, as well as associated emissions of atmospheric trace gases such as $\mathrm{N}_{2} \mathrm{O}, \mathrm{CH}_{4}$ and $\mathrm{CO}_{2}$. From 3 to 23 December 2012, R/V Meteor (M91) cruise took place in the Peruvian upwelling system between 4.59 and $15.4^{\circ} \mathrm{S}$, and 82.0 to $77.5^{\circ} \mathrm{W}$. During M91 we investigated the composition of the sea-surface microlayer (SML), the oceanic uppermost boundary directly subject to high solar radiation, often enriched in specific organic compounds of biological origin like chromophoric dissolved organic matter (CDOM) and marine gels. In the SML, the continuous photochemical and microbial recycling of organic matter may strongly influence gas exchange between marine systems and the atmosphere. We analyzed SML and underlying water (ULW) samples at 38 stations focusing on CDOM spectral characteristics as indicator of photochemical and microbial alteration processes. CDOM composition was characterized by spectral slope $(S)$ values and excitation-emission matrix fluorescence (EEMs), which allow us to track changes in molecular weight (MW) of DOM, and to determine potential DOM sources and sinks. Spectral slope $S$ varied between 0.012 to $0.043 \mathrm{~nm}^{-1}$ and was quite similar between SML and ULW, with no significant differences between the two compartments. Higher $S$ values were observed in the ULW of the southern stations below $15^{\circ} \mathrm{S}$. By EEMs, we identified five fluorescent components (F1-5) of the CDOM pool, of which two had excitation/emission characteristics of aminoacid-like fluorophores (F1, F4) and were highly enriched in
\end{abstract}

the SML, with a median ratio SML: ULW of 1.5 for both fluorophores. In the study region, values for CDOM absorption ranged from 0.07 to $1.47 \mathrm{~m}^{-1}$. CDOM was generally highly concentrated in the SML, with a median enrichment with respect to the ULW of 1.2. CDOM composition and changes in spectral slope properties suggested a local microbial release of DOM directly in the SML as a response to light exposure in this extreme environment. In a conceptual model of the sources and modifications of optically active DOM in the SML and underlying seawater (ULW), we describe processes we think may take place (Fig. 1); the production of CDOM of higher MW by microbial release through growth, exudation and lysis in the euphotic zone, includes the identified fluorophores (F1, F2, F3, F4, F5). Specific amino-acidlike fluorophores $(\mathrm{F} 1, \mathrm{~F} 4)$ accumulate in the SML with respect to the ULW, as photochemistry may enhance microbial CDOM release by (a) photoprotection mechanisms and (b) cell-lysis processes. Microbial and photochemical degradation are potential sinks of the amino-acid-like fluorophores $(\mathrm{F} 1, \mathrm{~F} 4)$, and potential sources of reworked and more refractory humic-like components (F2, F3, F5). In the highly productive upwelling region along the Peruvian coast, the interplay of microbial and photochemical processes controls the enrichment of amino-acid-like CDOM in the SML. We discuss potential implications for air-sea gas exchange in this area. 


\section{Introduction}

The Peruvian eastern boundary upwelling system (EBUS), extending along the coast off Peru between $4^{\circ}$ and about $40^{\circ}$ south, is among the most productive marine ecosystems worldwide (Capone and Hutchins, 2013; Chavez and Messié, 2009; Rosenberg et al., 1983) and it is characterized by high biological activity, involving high export rates of organic carbon both vertically and laterally (Arístegui et al., 2004; Muller-Karger et al., 2005). The high productivity is sustained by winds year-round that promote the upwelling of nutrient-rich deep waters into the euphotic zone, thus favoring phytoplankton photosynthesis and organic matter production (Chavez and Messié, 2009). High rates of organic matter production are counterbalanced by heterotrophic respiration, which provides sinks for the oxygen produced by autotrophs and leads to subsurface oxygen minimum zones (OMZs) (Lachkar and Gruber, 2011). OMZs are expanding worldwide due to reduced solubility at increasing temperatures, as well as a consequence of reduced oceanic ventilation and enhanced stratification (Keeling et al., 2010; Stramma et al., 2008). OMZs become increasingly important as key marine regions for the emission of climate-relevant gases like carbon dioxide $\left(\mathrm{CO}_{2}\right)$, methane $\left(\mathrm{CH}_{4}\right)$, nitrous oxide $\left(\mathrm{N}_{2} \mathrm{O}\right)$ and hydrogen sulfide $\left(\mathrm{H}_{2} \mathrm{~S}\right)$ (Paulmier et al., 2008, 2011). $\mathrm{N}_{2} \mathrm{O}$ is a strong greenhouse gas and ozone-reactive: $30 \%$ of its atmospheric concentration has an oceanic source (Solomon et al., 2007), of which, up to $75 \%$ is supported by OMZs (Bange et al., 2001). Therefore, OMZs are key environments to assess the oceanic contribution to the concentration of atmospheric gases. Defining the processes that regulate gas fluxes across the water-air interface is a central objective to better understand the reciprocal relationship between changes in our climate and marine environments.

The uppermost oceanic layer in contact with the atmosphere is the sea-surface microlayer (SML), which mediates major climate-relevant processes including air-sea gas exchange and sea-spray aerosol emission (Liss and Duce, 2005). This interface between a liquid (hydrosphere) and a gas phase (atmosphere) accumulates organic matter of biological origin, creating a sort of "skin" of surface-active compounds able to dampen capillary waves and "capping the flux" of gases across the water-air interface (GESAMP, 1995). Natural organic compounds in the SML include a vast array of photosynthesis products including carbohydrates, amino acids and lipids, as well as other carbon-rich compounds like dissolved organic matter (DOM) and marine gels (e.g., Cunliffe et al., 2013). The DOM pool represents a continuum of molecular weights and biological lability ranging from refractory to labile DOM that is either utilized rapidly by microorganisms (Benner, 2002; Carlson, 2002) or photochemically degraded (Kieber, 2000). These compounds, produced in the oceanic photic zone and brought to the SML through rising bubbles (Hardy, 1982), contribute to the enrichment of a natural surface biofilm and favor specific SML heterotrophic communities that are very active in recycling this organic material (Hardy, 1982; Cunliffe et al., 2011). While bulk dissolved organic carbon is not generally enriched in the SML, specific DOM fractions are present occasionally at much higher concentrations than in the underlying water (Cunliffe et al., 2013). These enriched pools of organic matter include marine gel particles (Wurl and Holmes, 2008), chromophoric dissolved organic matter (CDOM) (Zhang and Yang, 2013; Tilstone et al., 2010) and phenolic material (Carlson, 1982; Carlson and Mayer, 1980).

$\mathrm{CDOM}$ is the principal light-absorbing constituent of DOM, strongly absorbing UV (100-400 nm) and visible radiation (400-700 nm), and it can comprise $20-70 \%$ of the DOM in oceanic waters (Coble, 2007). CDOM plays a major role in the attenuation of UV wavelengths and can reduce the availability of underwater photosynthetically active radiation for primary production (Bracchini et al., 2011). Photolysis of CDOM promotes the formation of low molecular weight (LMW) compounds from the breakdown of high molecular weight DOM (HMW-DOM), facilitating the bioavailability of carbon uptake for microbial growth from biologically refractory material, and representing an important loss pathway for CDOM in the oceans (Kieber et al., 1989). Other major byproducts of CDOM photolysis are carbon monoxide (CO), which often exists at supersaturated concentrations in the oceans' surface (Blough, 2005, and references therein), $\mathrm{CO}_{2}$ (Miller and Zepp, 1995) and reactive chemical species (Loiselle et al., 2012). To initiate a photochemical reaction, light must first be absorbed and in this respect the SML is very well exposed to elevated solar radiation (Liss and Duce, 2005). CDOM photolysis may affect biological processes within the SML as well as the structure of accumulated organic matter. Optical properties and photochemical cycling of DOM have been widely investigated in the ocean: CDOM alters light spectra in the surface ocean and its spatial and temporal distribution have been used in characterizing water masses exchange (Nelson and Siegel, 2013). However, processes within the SML remain poorly understood. Possible effects of photochemistry on SML chemical composition have been discussed in the past (Blough, 2005), but still little is known on CDOM fluorophores, sources and sinks (Tilstone et al., 2010; Zhang and Yang, 2013). To discern sources, sinks and modification of DOM in surface waters, whether microbially or photochemically induced, we investigated optical properties of organic sea-surface microlayers and underlying water samples in the highly productive EBUS off the coast of Peru. We applied optical spectroscopy measurements combined with chemical and biological analysis to identify different compounds within the CDOM pool and their partitioning between the SML and the underlying water. The use of excitation-emission matrix fluorescence spectroscopy (EEMs) allowed us to discriminate different compound classes in the SML and underlying water based on their excitation and emission maxima (Coble, 1996). 
At present, the oceans are subject to many changes in physical and chemical properties like $\mathrm{pH}$, temperature, and dissolved oxygen concentration, which potentially will affect the biological cycling of carbon (Riebesell et al., 2009; Keeling et al., 2010; Bopp et al., 2002). Whether the oceans are sources or sinks of carbon depends on the production rate of organic matter with respect to its biological degradation (Del Giorgio and Duarte, 2002), and high DOM degradation in the SML might represent a net source of $\mathrm{CO}_{2}$ to the atmosphere (Garabétian, 1990). It is well known that the composition of the SML reflects biological processes of the euphotic zone (Galgani et al., 2014; Gao et al., 2012; Matrai et al., 2008; Bigg et al., 2004), and that elevated concentrations of organic matter may accumulate in the SML in highly productive regions like the Peruvian EBUS (Engel and Galgani, 2016). The enrichment of light-absorbing DOM in the SML may increase the photochemical formation and fluxes of reactive chemical species at the surface, with potentially important consequences for the composition of the SML itself and for the fate of compounds passing through this interface (Blough, 2005). Last but not least, the photochemical DOM breakdown may increase the biological availability of carbon, thus increasing heterotrophic respiration and $\mathrm{CO}_{2}$ flux to the atmosphere.

CDOM contributes to the dissolved organic carbon (DOC) pool, but while DOC is a bulk measure, CDOM is a characteristic of DOM rather than a discrete class of compounds (Nelson and Siegel, 2013). Positive correlations have been observed between CDOM and DOC in coastal systems and plankton enclosures (Loginova et al., 2015), but the strength of these correlations varies much across regional and seasonal differences (Blough and Del Vecchio, 2002). CDOM is a precursor for photochemical reactions that may drive the emission of trace gases from photochemically altered DOM (e.g., Ciuraru et al., 2015). Therefore, in upwelling areas associated with OMZs, CDOM characteristics in the SML are worth being investigated as they may impact the exchange of gases between the ocean and the atmosphere.

\section{Material and methods}

\subsection{Study area}

The R/V Meteor cruise M91 was an integrated biogeochemical study in the upwelling region off the coast of Peru, with the aim to assess the importance of oxygen minimum zones (OMZs) for the air-sea exchange of gases relevant for climate and tropospheric chemistry (Bange, 2013). A total of 39 samples for SML and underlying water were collected in December 2012 between 5 and $16^{\circ} \mathrm{S}$ off the Peruvian coast. Data that we report here additionally from what previously described by Engel and Galgani (2016) refer to 38 stations. For easiness of comparison, Table 1 recalls salinity, water
Table 1. Data on average, maximum and minimum salinity, water temperature, global radiation and wind speed during M91. Data were retrieved from Dship data server of R/V Meteor.

\begin{tabular}{lrrrc}
\hline & $\begin{array}{r}\text { Salinity } \\
(\mathrm{PSU})\end{array}$ & $\begin{array}{r}\text { Temperature } \\
\left({ }^{\circ} \mathrm{C}\right)\end{array}$ & $\begin{array}{r}\text { Global radiation } \\
\left(\mathrm{W} \mathrm{m}^{-2}\right)\end{array}$ & $\begin{array}{r}\text { Wind speed } \\
\left(\mathrm{m} \mathrm{s}^{-1}\right)\end{array}$ \\
\hline Average & 34.9 & 19.2 & 539 & 5.5 \\
SD & 0.2 & 1.7 & 352 & 2.1 \\
Min & 34.4 & 15.9 & 10 & 0.6 \\
Max & 35.3 & 21.9 & 1088 & 9.0 \\
\hline
\end{tabular}

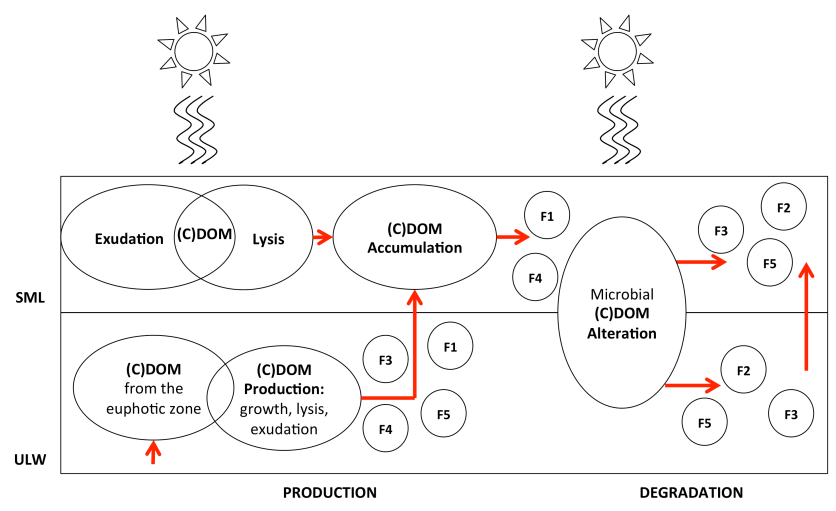

Figure 1. Conceptual model of the sources and modifications of optically active DOM in the SML and underlying seawater in the upwelling region off the coast of Peru during the SOPRAN M91 cruise.

temperature, radiation and wind speed, as already described in the companion manuscript (Engel and Galgani, 2016).

Some stations were revisited for multiple sampling (Table 2): S7 and S7_2; S12_1, S12_2, and S12_3; S16_1, S16_2, S16_3; S20 and S20_2. These stations were sampled within a time frame of $24 \mathrm{~h}$ for SML and ULW (underlying water), as we were interested in monitoring the evolution of CDOM optical properties in the SML and ULW at different times of the day depending on the solar irradiation. Whenever possible, we sampled at sunrise, midday and sunset. For security reasons, it was not possible to sample later than sunset, as the zodiac operations were not allowed out at dark. Exact latitude and longitude measurements were not always possible to retrieve after a certain time, but were similar for the stations sampled in a few hours time lag.

The sampling approach for the SML was chosen as a silicate glass plate of $500 \mathrm{~mm}$ (length) $\times 250 \mathrm{~mm}$ (width) $\times 5 \mathrm{~mm}$ (thickness) with an effective sampling area of $2000 \mathrm{~cm}^{2}$ as indicated in Engel and Galgani (2016). Briefly, the glass plate was inserted into the water perpendicular to the surface and withdrawn at a controlled rate of $\sim 20 \mathrm{~cm} \mathrm{~s}^{-1}$ as first suggested by Harvey and Burzell (1972). Different devices can be applied to sample the SML. The glass plate approach we choose collects a thinner SML $(\sim 60-150 \mu \mathrm{m})$ when compared to, e.g., the Garrett screen 

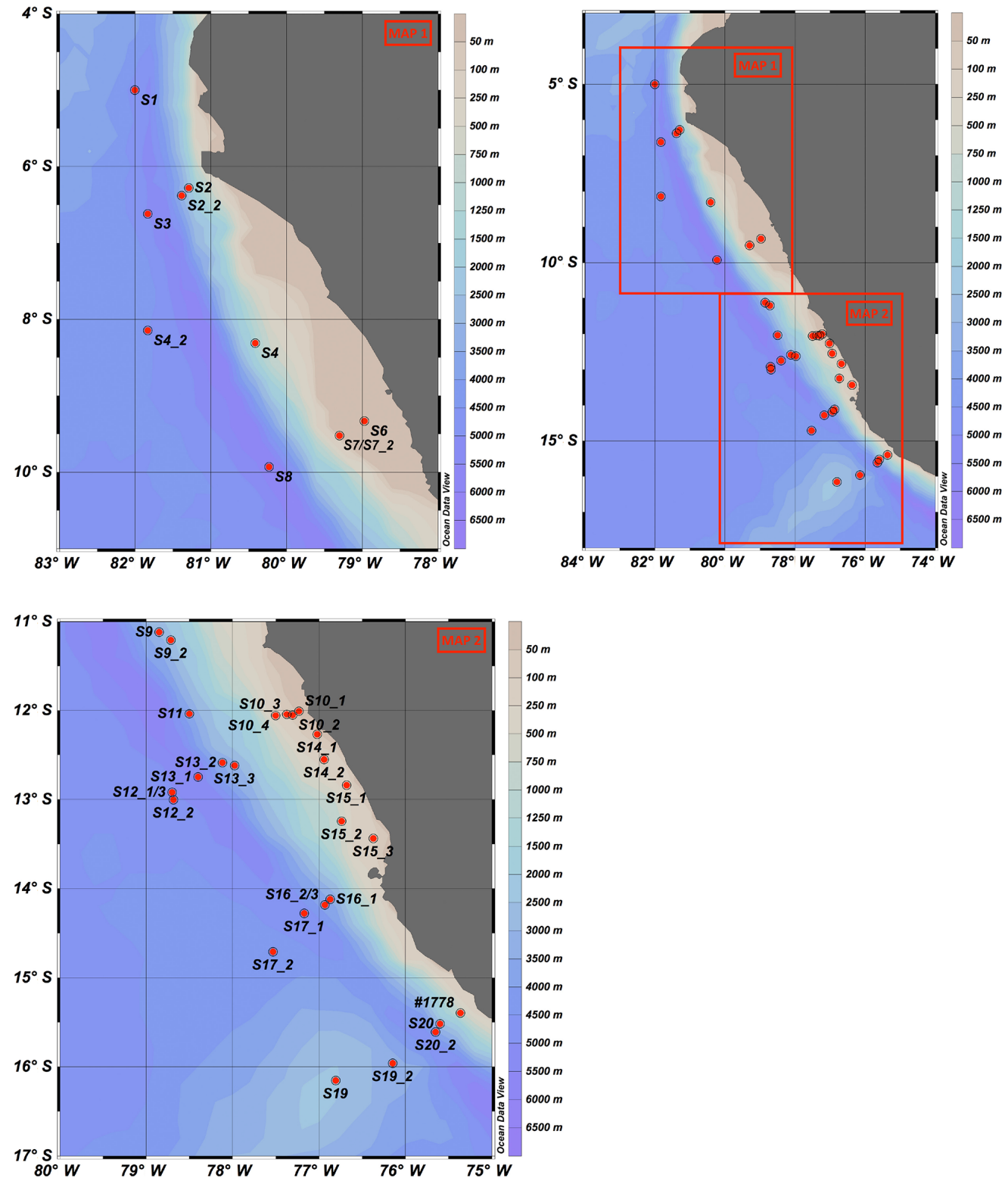

Figure 2. Maps showing all sampled stations. Stations with multiple measurements are: (1) S7/7_2, (2) S12_1/3 and S12_2, (3) S16_1, S16_2/3, (4) S20 and S20_2. The locations of S7 and S7_2; S12_1 and S12_3; S16_2 and S16_3 coincide, as sampling was performed at different times.

$(150-300 \mu \mathrm{m})$, one of the mainly recognized practices introduced by Garrett in 1965 (Cunliffe et al., 2011; Garrett, 1965). The glass plate was chosen because it allows the sampling of enough volume required for analysis while keeping a minimal dilution with underlying water. Sampling was performed on a rubber boat; in order to obtain a wellstandardized procedure and to minimize biases by sampling, the same person always took the samples with a repeatable withdrawal speed of the SML. The rubber boat was positioned as far upwind of the ship as possible and away from the path taken by the ship in order to avoid any potential sur- face contamination. The outboard motor of the rubber boat was switched off and samples were collected in upwind clean waters.

Before collecting the sample into the bottle, we let the plate drain for $20 \mathrm{~s}$ approximately. Then, the sample retained on both sides of the plate was removed with a Teflon wiper, and the procedure repeated about 20 times to obtain the necessary volume for analysis. The exact amount of dips per sample has been tracked. The first sample was discarded and used to rinse the collecting bottle $(\mathrm{HCl} 10 \%$ cleaned and Milli-Q rinsed). Glass plate and wiper were acid cleaned 
Table 2. Stations with multiple measurements. Metadata with date, local and UTC time of sampling, coordinates, and average global radiation retrieved from Dship data server of R/V Meteor.

\begin{tabular}{|c|c|c|c|c|c|c|c|c|c|}
\hline $\begin{array}{l}\text { Station Ship } \\
\text { ID }\end{array}$ & Nr. & Station nr. & Samples & Date & $\begin{array}{l}\text { Time } \\
\text { (UTC) }\end{array}$ & $\begin{array}{l}\text { Time } \\
\text { (Local) }\end{array}$ & $\begin{array}{l}\text { Lat, } S \\
\left({ }^{\circ}\right)\end{array}$ & $\begin{array}{l}\text { Long, W } \\
\left({ }^{\circ}\right)\end{array}$ & $\begin{array}{r}\text { Average Global } \\
\text { Radiation } \\
{\left[\mathrm{W} \mathrm{m}^{-2}\right]}\end{array}$ \\
\hline $1733-5$ & 1 & S7 & SML/ULW & $08-12-12$ & $11: 30$ & $6: 30$ & $9^{\circ} 31^{\prime} 15.52^{\prime \prime}$ & $79^{\circ} 17^{\prime} 53.16^{\prime \prime}$ & 10 \\
\hline $1733-9$ & & S7_2 & SML/ULW & $08-12-12$ & $19: 45$ & $14: 45$ & $9^{\circ} 31^{\prime} 15.52^{\prime \prime}$ & $79^{\circ} 17^{\prime} 53.16^{\prime \prime}$ & 837 \\
\hline $1752-2$ & 2 & S12_1 & SML/ULW & $13-12-12$ & $12: 00$ & $7: 00$ & $12^{\circ} 55^{\prime} 12.17^{\prime \prime}$ & $78^{\circ} 42^{\prime} 0.07^{\prime \prime}$ & 380.5 \\
\hline $1752-7$ & & S12_2 & SML/ULW & $13-12-12$ & $20: 30$ & $15: 30$ & $13^{\circ} 0^{\prime} 19^{\prime \prime}$ & $78^{\circ} 40^{\prime} 59.99^{\prime \prime}$ & 704.5 \\
\hline $1752-9$ & & $\mathrm{~S} 12 \_3$ & SML/ULW & $13-12-12$ & $23: 10$ & $18: 10$ & $12^{\circ} 55^{\prime} 19.99^{\prime \prime}$ & $78^{\circ} 42^{\prime} 2.99^{\prime \prime}$ & 47 \\
\hline & 3 & S16_1 & SML/ULW & $17-12-12$ & $12: 40$ & $7: 40$ & $14^{\circ} 7^{\prime} 14.08^{\prime \prime}$ & $76^{\circ} 52^{\prime} 13.08^{\prime \prime}$ & 381 \\
\hline $1764-6$ & & S16_2 & SML/ULW & $17-12-12$ & $17: 40$ & $12: 40$ & $14^{\circ} 11^{\prime} 5.92^{\prime \prime}$ & $76^{\circ} 55^{\prime} 59.44^{\prime \prime}$ & 1043 \\
\hline $1764-9$ & & S16_3 & SML/ULW & $17-12-12$ & $22: 00$ & $17: 00$ & $14^{\circ} 11^{\prime} 5.92^{\prime \prime}$ & $76^{\circ} 55^{\prime} 59.44^{\prime \prime}$ & 161.5 \\
\hline $1777-2$ & 4 & $\mathrm{~S} 20^{-}$ & SML/ULW & $22-12-12$ & $18: 00$ & $13: 00$ & $15^{\circ} 31^{\prime} 10.41^{\prime \prime}$ & $75^{\circ} 36^{\prime} 0.93^{\prime \prime}$ & 1088 \\
\hline $1777-10$ & & S20_2 & SML/ULW & $23-12-12$ & $15: 00$ & 10:00 & $15^{\circ} 36^{\prime} 42^{\prime \prime}$ & $75^{\circ} 39^{\prime} 0^{\prime \prime}$ & 1046 \\
\hline
\end{tabular}

( $\mathrm{HCl} 10 \%)$ and Milli-Q rinsed prior use, and at sampling site they were copiously rinsed with in situ seawater to minimize any contamination with alien material during transport and handling. Underlying seawater (ULW) was collected right after SML at about $\sim 20 \mathrm{~cm}$ depth by opening an acid cleaned ( $\mathrm{HCl} 10 \%)$ and Milli-Q rinsed glass bottle and closing it underwater. The thickness $(d, \mu \mathrm{m})$ of our reference SML that we were able to collect was estimated as follows:

$d=V /(A \times n)$,

where $V$ is the SML volume collected; i.e., $60-140 \mathrm{~mL}, A$ is the sampling area of the glass plate $\left(A=2000 \mathrm{~cm}^{2}\right)$ and $n$ is the number of dips. During this cruise, the apparent sampling thickness of the SML ranged between 45 and $60 \mu \mathrm{m}$, with an overall mean of $49 \pm 8.9 \mu \mathrm{m}$ (Engel and Galgani, 2016). Many factors may influence the thickness of the SML such as withdrawal rate, dipping time, and plate dimensions. With a withdrawal speed of $\sim 20 \mathrm{~cm} \mathrm{~s}^{-1}$, the apparent SML thickness was in accordance with previous findings at similar withdrawal rate reporting 60-100 $\mu \mathrm{m}$ (Harvey and Burzell, 1972) and 50-60 $\mu \mathrm{m}$ (Zhang et al., 1998). The sampling thickness was very well comparable among all stations, indicating that no major biases due to sampling procedure may have occurred.

After sampling, bottles were stored in the dark and the samples immediately processes in the laboratory onboard, within maximum $30 \mathrm{~min}$ from sampling.

\subsection{Chemical and biological analyses}

\subsubsection{Dissolved organic matter (DOM)}

Sampling, calibration and analysis procedure for dissolved organic carbon (DOC) and for dissolved hydrolyzable amino acids (DHAA), have been described in details in Engel and Galgani (2016). Additionally, to track DOM diagenetic state and bioavailability, we used the carbon-normalized yields of dissolved amino acids to DOC, expressed as DHAA\%DOC (Amon and Fitznar, 2001; Benner, 2002; Kaiser and
Benner, 2009; Davis and Benner, 2007). Amino acids generally comprise a large fraction of bioavailable organic matter and are preferentially consumed by microbial activity quite rapidly. In surface waters they may be easily photodegraded too. Therefore, the amount of carbon included in amino acids is considered as a good indicator of DOM diagenesis and a value of $\sim 2 \%$ of DHAA\%-DOC may indicate the threshold between labile and semi-labile and refractory DOM (Davis and Benner, 2007).

Samples for chromophoric and fluorescent DOM (CDOM and FDOM) were filtered through $0.45 \mu \mathrm{m}$ PES syringe filters and collected into $40 \mathrm{~mL}$ pre-combusted $\left(8 \mathrm{~h}, 500^{\circ} \mathrm{C}\right)$ amber glass vials. Samples were stored in the dark at $4{ }^{\circ} \mathrm{C}$ with no other treatment than pre-filtering. Since storage procedures may affect the absorbance and fluorescence properties of DOM, absorbance and fluorescence readings were performed directly on-board within a few hours from sampling or the next day according to Schneider-Zapp and colleagues (2013). Prior to measurements, samples were stored in the dark and acclimatized at room temperature. For CDOM, triplicate absorbance measurements were made on a Shimadzu $1800 \mathrm{UV}$-visible spectrophotometer in the range 220 to $700 \mathrm{~nm}$ with $0.5 \mathrm{~nm}$ increments, in a $10 \mathrm{~cm}$ pathlength quartz cuvette against Milli-Q water as a reference. For FDOM, 3-D fluorescence spectroscopy was performed with a Varian Cary Eclipse Fluorescence Spectrophotometer equipped with a xenon flash lamp and data assembled into excitation-emission matrices (EEMs) which enable to individuate single DOM fluorophores (Coble, 1996) and to perform parallel factor analysis PARAFAC (Stedmon and Bro, 2008). Samples have been acclimatized and scanned at a fixed $20^{\circ} \mathrm{C}$ temperature (Cary Single Cell Peltier Accessory, Varian) in $1 \mathrm{~cm}$ path length quartz cuvette. Scans were performed at $600 \mathrm{~nm} \mathrm{~min}^{-1}$ using an excitation range (Ex) of 240-450 nm with $5 \mathrm{~nm}$ increments and recorded emission (Em) in the range $242-600 \mathrm{~nm}$ with $2 \mathrm{~nm}$ increments. Samples were run in a mode of $5 \mathrm{~nm}$ slit for both excitation and emission and $0.1 \mathrm{~s}$ integration time. 


\subsubsection{Particulate organic carbon (POC) and gel particles}

Total numbers of gel particles were determined by microscopy after Engel (2009). A detailed description of the method used during M91 cruise can be found in Engel and Galgani (2016). POC data were retrieved after Engel and Galgani (2016). We refer to this companion publication for further analytical details.

\subsubsection{Phytoplankton and heterotrophic bacteria}

Samples, calibration and analysis for phytoplankton and heterotrophic bacteria counts for M91 are described in details in Engel and Galgani (2016).

\subsection{Data analysis}

\subsubsection{CDOM}

The measured absorbance at every wavelength $\lambda$ was converted to absorption coefficient $a(\lambda),\left(\mathrm{m}^{-1}\right)$, according to the following equation (Bricaud et al., 1981):

$a(\lambda)=2.303 A_{\lambda} / L$

where $A_{\lambda}$ is the absorbance and $L$ is the path-length of the cuvette (here $0.10 \mathrm{~m}$ ). Absorbance is an optical characteristic of CDOM, which allows quantifying the amount of CDOM in the samples. Therefore, the absorption coefficient $a(\lambda)$ is considered as a proxy for CDOM concentration. To estimate CDOM concentration, we calculated the absorption coefficient at $325 \mathrm{~nm}$ as often used for the open ocean (Swan et al., 2009; Nelson and Siegel, 2013). The dependence of $a$ on the wavelength was determined by analyzing the spectral slope parameter $S\left(\mathrm{~nm}^{-1}\right)$ in the discrete wavelength ranges of 275-295 and 350-400 nm, determined by linear regression of log-transformed absorption spectra against the wavelength (Bricaud et al., 1981; Helms et al., 2008):

$a(\lambda)=a\left(\lambda_{0}\right) e^{-S\left(\lambda-\lambda_{0}\right)}$

where $a\left(\lambda_{0}\right)$ is the absorption coefficient at a reference wavelength $\lambda_{0} . S$ measured in the wavelength range $275-295 \mathrm{~nm}$ $\left(S(275-295), \mathrm{nm}^{-1}\right)$ and $350-400 \mathrm{~nm}\left(S(350-400), \mathrm{nm}^{-1}\right)$ as well as slope ratio (SR) defined as $S(275-295)$ : $S(350$ 400) are good indicators to characterize CDOM (Helms et al., 2008). SR is characterized by lower values for terrestrial CDOM compared to CDOM produced by autochthonous marine sources and instead of $S$ alone, could be a more sensitive indicator of photochemically induced changes in the molecular weight of the CDOM pool as an increase in SR suggests photodegradation processes, while a decrease is often related to microbially altered CDOM (Helms et al., 2008). Both S(275-295) and SR increase with (a) irradiation (photobleaching), (b) with decreasing DOM molecular weight, and (c) at higher salinity reflecting mixing of water masses along a salinity gradient. As such they are useful as tracers to determine mixing and coastal inputs. We also determined the SUVA $_{254}$ index, that is, the specific ultraviolet absorbance (A) at $254 \mathrm{~nm}$ normalized to DOC concentration. This index was shown to correlate significantly with increasing aromaticity of DOM (Weishaar et al., 2003):

$\operatorname{SUVA}_{254}\left(\mathrm{mg} \mathrm{C} \mathrm{L}^{-1} \mathrm{~m}^{-1}\right)=A(254)\left(\mathrm{m}^{-1}\right) / \operatorname{DOC}\left(\mathrm{mgL}^{-1}\right)$

\subsubsection{FDOM}

The 3-D recorded spectra were corrected for the instrumental biases both for excitation and emission using correction curves provided by the manufacturer (Stedmon and Bro, 2008). Additionally, spectra were corrected against a Milli$\mathrm{Q}$ water blank run every day before the samples to remove water Raman peaks. No correction for inner filter effects was applied to our data as for each sample the relative $a(\lambda)$ value was below $10 \mathrm{~m}^{-1}$ (Lawaetz and Stedmon, 2009; Stedmon and Bro, 2008). As an example, $a(254)$ was on average $2 \pm 2 \mathrm{~m}^{-1}$ for SML and $1.6 \pm 1.3 \mathrm{~m}^{-1}$ for underlying water (ULW) samples. Fluorescence spectra were normalized to Raman units (R.U.) by integrating the Raman peak of $350 \mathrm{~nm}$ Ex and 382 to $407 \mathrm{~nm}$ Ex extracted by the daily Milli-Q water blank. Calibration to R.U. was done with the FDOMcorrect toolbox for Matlab (The MathWorks Inc.) incorporated in DrEEM toolbox (Murphy et al., 2013). We choose to normalize to R.U. as these units are widely used in open ocean measurements and we could compare our results.

PARAFAC analysis was applied to EEMs in order to identify and quantify independent underlying components of the CDOM pool, and was performed by the N-way toolbox for Matlab in DrEEM (Murphy et al., 2013). After normalization to Raman units, data were smoothed to remove remaining scatter peaks, Raman and Rayleigh signals by creating a sub-data set. We then performed a preliminary outlier analysis generating models with 3 to 7 factors with non-negativity constraints, comparing the spectra to unconstrained models. When dilution dominates the data set, components are strongly correlated. To investigate biases due to dilution, we performed a test for correlations between the components, as suggested by the DrEEM tutorial by Murphy et al. (2013). We then normalized the data set by the DrEEm function normeem to reduce the co-linearity related to the concentration, thus giving low-concentrated samples a possibility to enter the model, followed by the outlier test again on the normalized data. After visually comparing the spectra and looking at the error residuals for models with 4 to 7 components, we then compared the models by the sum of squared errors (SSE) expressed as a function of wavelength, choosing the models with lower SSE. At this stage, we choose models with 5, 6 and 7 components and reversed the normalization to obtain the unscaled scores before validation. Models with 5, 6 and 7 components were validated by split half analysis " $\mathrm{S}_{4} \mathrm{C}_{6} \mathrm{~T}_{3}$ " (see Murphy et al., 2013), where it was ensured that in each test the data set halves being compared 
had no samples in common. The validation was successful for 5-components model, for all comparison. The maximum fluorescence intensities of the five fluorophores at specific Ex-Em wavelengths ranges are described in Table 3. Figures with the model comparison for both excitation and emission for the 5-components model are included in the Supplement (Figs. S1 and S2 in the Supplement).

In fluorescence spectroscopy, the humification index (HIX), first introduced by Zsolnay et al. (1999), is a powerful tool to study CDOM dynamics in soils, as humification is associated with a shift to longer emission wavelengths (Senesi, 1990). It has been first applied to aquatic CDOM in estuarine waters by Huguet et al. (2009), and is calculated as the ratio $\mathrm{H} / \mathrm{L}$ of two spectral region areas of the emission spectrum scanned at $254 \mathrm{~nm}$ excitation. Area $\mathrm{L}$ is calculated between the emission wavelengths 300 and $345 \mathrm{~nm}$, and area $\mathrm{H}$ between 435 and $480 \mathrm{~nm}$. When the degree of aromaticity of CDOM increases, the emission spectrum at excitation $254 \mathrm{~nm}$ is shifted towards the red (longer wavelengths), implying an increase in $\mathrm{H} / \mathrm{L}$ ratio and in HIX. High HIX implies maximum fluorescence intensity at long wavelengths and therefore the presence of complex molecules like HMW aromatic CDOM (Senesi et al., 1991). We applied a slight modification to the HIX index for our samples, introducing the "SMHIX" index, where SM stands for surface microlayer. As we did neither have the scanned excitation wavelength of $254 \mathrm{~nm}$, nor the scanned spectrum at excitation 345 and $435 \mathrm{~nm}$, we calculated SMHIX index as follows:

$\mathrm{SMHIX}=\left(\sum I_{434 \rightarrow 480}\right) /\left(\sum I_{300 \rightarrow 346}\right)$,

where $\sum I_{434 \rightarrow 480}$ is the sum of all fluorescence intensities at every emission wavelength between 434 and $480 \mathrm{~nm}$, and $\sum I_{300 \rightarrow 346}$ is the sum of all fluorescence intensities at every emission wavelength between 300 and $346 \mathrm{~nm}$, both scanned with excitation $=255 \mathrm{~nm}$.

\subsubsection{Enrichment factors}

Enrichment factors (EFs), allow tracking of accumulation patterns of any compound in the SML with respect to the underlying water (ULW) and comparison among different compounds. EFs are calculated according to the following:

$\mathrm{EF}=[X]_{\mathrm{SML}} /[X]_{\mathrm{ULW}}$,

where $[X]$ is the concentration of a given parameter in the SML or ULW, respectively (GESAMP, 1995). EF $>1$ indicates an enrichment, EF $<1$ indicates a depletion in the SML. EFs are normally used for quantitative parameters, i.e., measured in abundance and concentration such as DOC, DHAA, CDOM, marine gels and cell abundances. Here, we applied the EF calculation for qualitative ratios and indexes too, like S(275-295), SR, SMHIX, SUVA 254 , DHAA\%-DOC. We kept the same wording, which is useful to describe dif- ferences between SML and ULW for both quantitative and qualitative parameters.

Statistical tests in data analysis have been accepted as significant for $p<0.05$. Calculations, statistical tests and illustration were performed with Microsoft Office Excel 2010, Sigma Plot 12.0 (Systat), Prism (GraphPad), Ocean Data View and Matlab R2009b (The MathWorks Inc.).

\section{Results}

Results on dissolved organic carbon and amino acids, gel particles (TEP and CSP), phytoplankton and bacterial abundance and the relative enrichment of these components in the SML of our sampling sites have been described elsewhere (Engel and Galgani, 2016). Here, we focus on the optical properties of DOM to identify possible sources, sinks and dynamics in the SML and underlying water of the Peruvian upwelling region.

\subsection{CDOM optical absorption properties}

In the upwelling region off the coast of Peru, values for CDOM absorption coefficient $a$ (325) ranged from 0.09 to $1.47 \mathrm{~m}^{-1}$ in the SML and from 0.07 to $1.47 \mathrm{~m}^{-1}$ in ULW. Highest values were observed at stations S10_ 1 to S10_4 along the coast for both SML and ULW (Fig. 3). CDOM was enriched in the SML at most stations (Figs. 4 and 5), with median EF for $a(325)=1.2$ in a range varying between 0.4 and 2.8. A median $\mathrm{EF}=1.2$ means that at least $50 \%$ of our observations accounted for a CDOM-enriched SML. Besides the southern transect, higher EF values were observed at the northern stations S2 and S2_2, and in the southern coastal upwelling stations S15_1 to S15_3. Lower EFs and EFs < 1, indicating a depletion of CDOM in the SML, were observed at higher distance from the coast (Fig. 5).

The spectral slope parameter between 275 and $295 \mathrm{~nm}$ $\left(S(275-295), \mathrm{nm}^{-1}\right)$ is a good indicator for CDOM molecular weight as an increase of this parameter indicates decreasing molecular weight, thus revealing accumulation or degradation processes of bioavailable CDOM (Helms et al., 2008). In our samples, $S(275-295)$ ranged from 0.012 to $0.038 \mathrm{~nm}^{-1}$ in the SML and from 0.017 to $0.043 \mathrm{~nm}^{-1}$ in ULW. In general, $S(275-295)$ was quite similar between SML and ULW, and no statistically significant differences were found between SML and ULW for S(275-295). Higher spectral slopes were observed in the ULW of the southern stations below $15^{\circ} \mathrm{S}$ (S19, S19_2, S20, S20_2, S1778). In the coastal stations S10_1 to S10_4 and S14_ 1 to S15_3 lower $S$ (275-295) values were determined for both SML and ULW (Fig. 3). Median enrichment factor (EF) for $S(275-$ 295) was 1 (Fig. 4), thus indicating similar molecular weight of CDOM compounds in the SML and ULW. Lower EFs were observed in the northernmost and southernmost stations and along the coast (Fig. 5). 
Table 3. Fluorescent components identified in this study in both SML and ULW samples, according to their Ex-Em maxima ranges (nm), maximum fluorescence intensity range Fmax (R.U.), corresponding peaks individuated in previous studies (peak name, region, Ex-Em ranges) and properties. EPS is defined as extracellular polymeric substances.

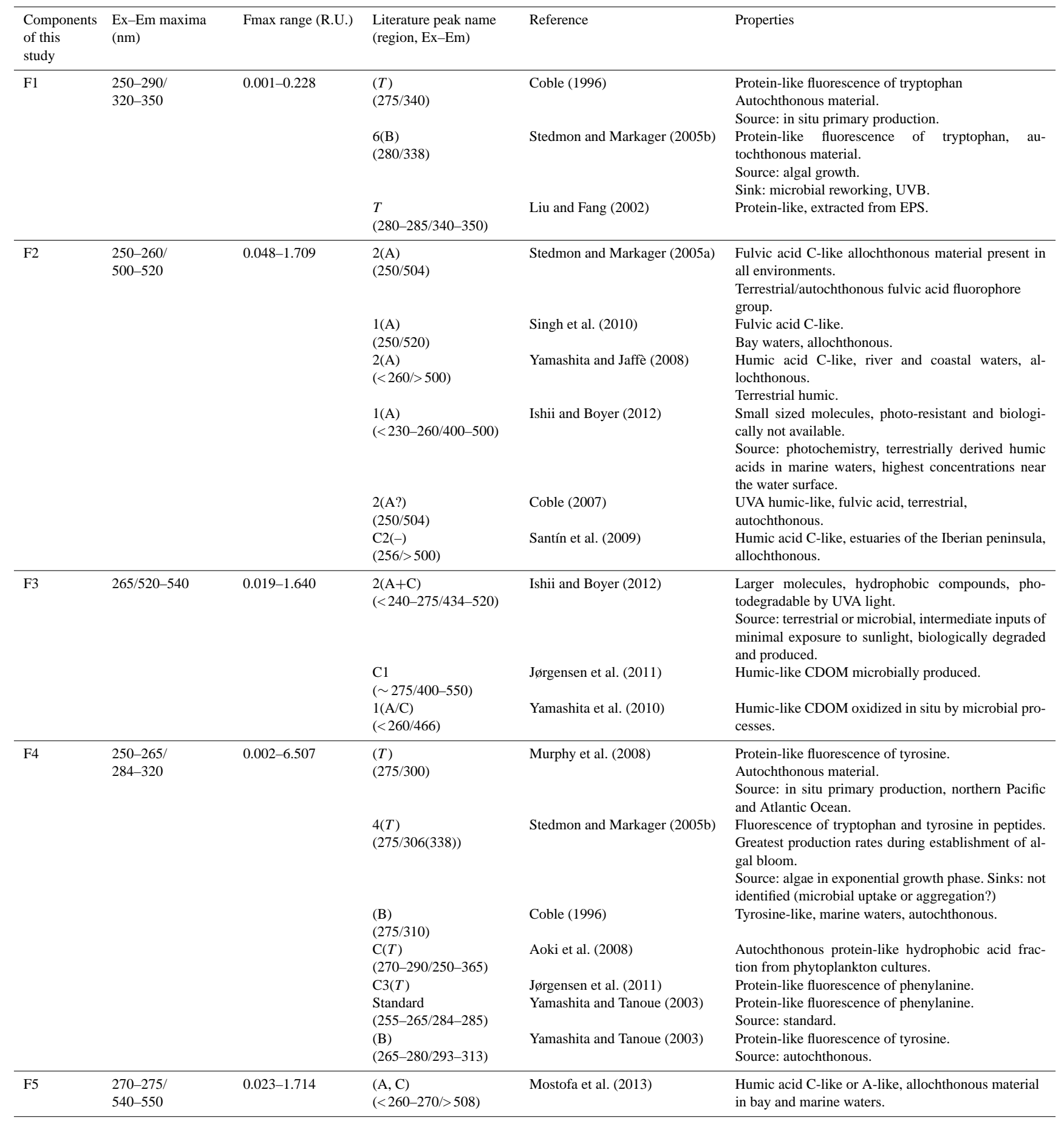

The SUVA 254 and SMHIX indexes are related to the degree of CDOM aromaticity and to its humic content, respectively. In our study, $\mathrm{SUVA}_{254}$ ranged from 0.49 to $1.74 \mathrm{mg} \mathrm{C} \mathrm{L}^{-1} \mathrm{~m}^{-1}$ in the SML, with highest values at coastal southern stations S10_1 to S10_4 and S14_1 to
S17_2. Similar values were recorded for ULW, ranging from 0.49 to $1.21 \mathrm{mg} \mathrm{CL}^{-1} \mathrm{~m}^{-1}$. Generally, $\mathrm{SUVA}_{254}$ values in our samples were comparable to the Pacific Ocean with a typical $\mathrm{SUVA}_{254}$ of $0.6 \mathrm{mg} \mathrm{C} \mathrm{L}^{-1} \mathrm{~m}^{-1}$ (Helms et al., 2008; Weishaar et al., 2003). Median EF for $\mathrm{SUVA}_{254}$ was 1.1, 

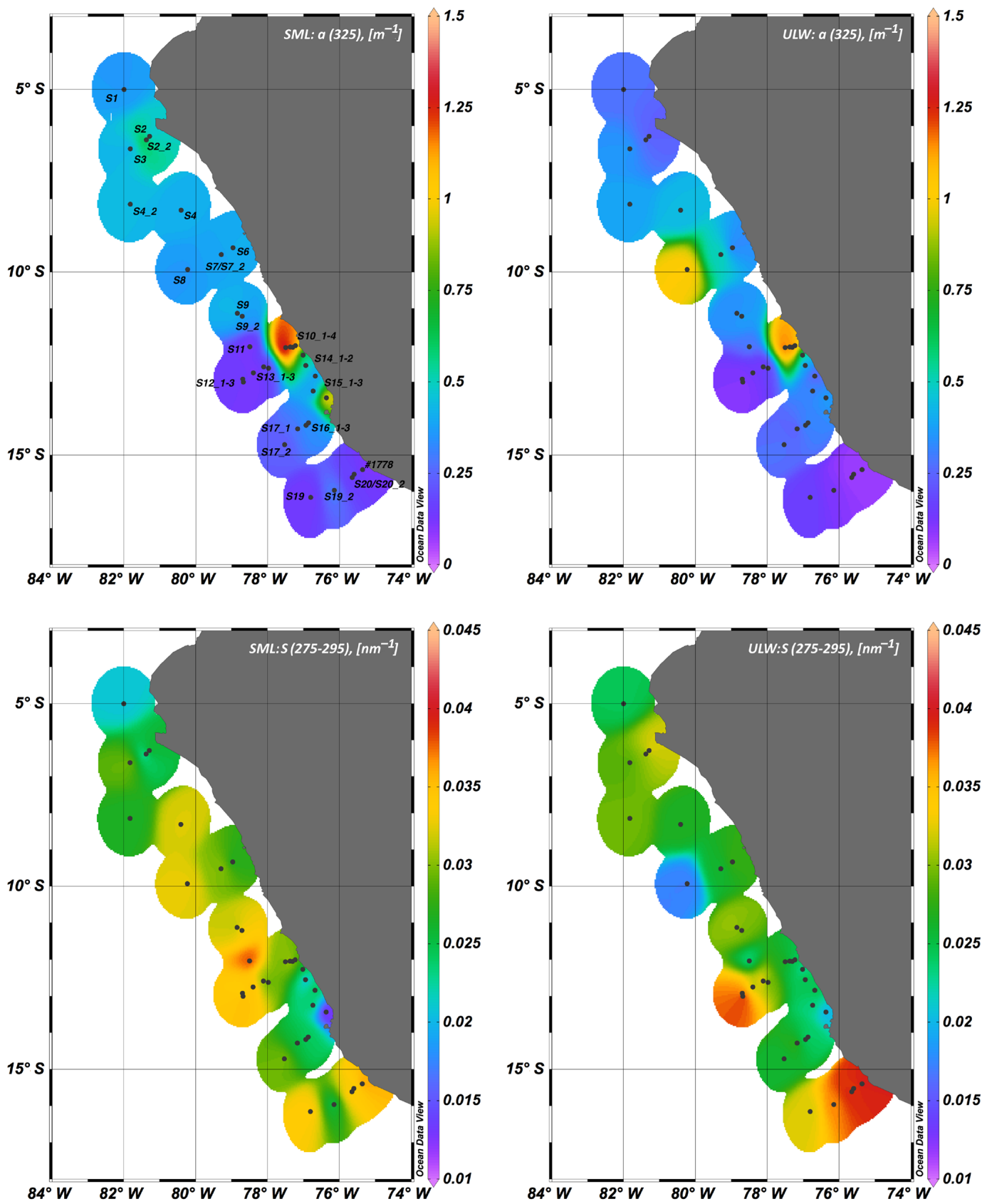

Figure 3. CDOM absorption coefficient $a(325),\left[\mathrm{m}^{-1}\right]$, in SML and underlying water (ULW) and spectral slope parameter between 275 and $295 \mathrm{~nm}, S(275-295),\left[\mathrm{nm}^{-1}\right]$.

with higher values in correspondence of northern stations and coastal southern stations (S2, S2_2, S15_1 to S15_3 and S19 to S1778), where the higher EFs for $a(325)$ were also observed (Figs. 4 and 5). SMHIX ranged from -1.33 to 2.05 for SML and from -0.1 to 3.03 for ULW, with highest values in ULW. Enrichment factors showed an overall depletion of high-humic acid containing CDOM in the SML (Fig. 4), with median $\mathrm{EF}=0.8$. Higher humic acid enrichment in the SML was observed on the southern transect S19 to S1778 (Fig. 5), where we recorded the highest enrichment of CDOM (as $a(325))$ as well.

The carbon-normalized yields of dissolved amino acids (DHAA\%-DOC) as indicator of DOM diagenetic state, ranged from 1.4 to $8.1 \%$ in SML samples and from 0.9 to $3.6 \%$ in ULW samples, indicating relatively more labile DOM in the SML. This observation was supported by the enrichment factors (EFs), which showed a general enrichment of more labile DOM in the SML (Fig. 4), with median EF 


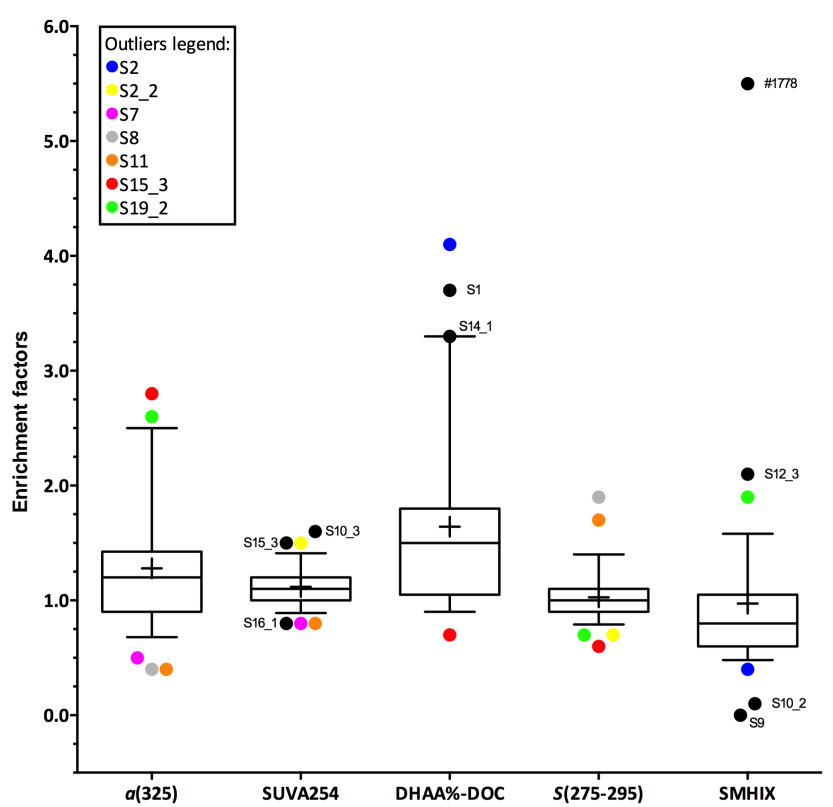

Figure 4. Box and Whiskers plot of enrichment factors for CDOM absorption coefficient $a(325)$, aromaticity (SUVA 254$)$, DOM diagenetic state (DHAA\%-DOC), spectral slope $S(275-295)$, and modified surface microlayer humification index (SMHIX). The horizontal lines of the boxes represent $25 \%, 50 \%$ (median) and $75 \%$ percentiles (from bottom to top). In the boxes, crosses represent the mean. Whiskers represent minimum and maximum values, and circles are outliers. Outliers are staggered to better visualize them. To identify the station, see outliers' labels and color legend. For $a(325)$, SUVA $_{254}$ and $S(275-295) n=38$. For SMHIX, $n=37$ and for DHAA $\%$-DOC $n=29$.

values for DHAA\%-DOC of 1.5. Highest EFs were recorded in the northernmost stations S1 to S3, and on the southernmost transect S19 to S1778 (Fig. 5).

\subsection{PARAFAC analysis for CDOM fluorophores}

Five optically active components were identified by PARAFAC analysis with the DrEEM toolbox in Matlab (Murphy et al., 2013), hereafter named F1, F2, F3, F4 and F5 (Fig. 6). The spectral characteristics of the five identified components were compared to previous studies as described in Table 3. F1 had an excitation range of 250-290 nm with emission peaks between 320 and $350 \mathrm{~nm}$, which corresponds to peak $T$ of the amino-acid-like fluorescence of tryptophan, derived by in situ primary production (Coble, 1996). This component (F1) was generally enriched in the SML (Figs. 7,8 ) with a median $\mathrm{EF}=1.5$, between a minimum EF of 0.5 and a maximum EF of 3.3. Potential loss processes of this compound are its destruction by UV light and microbial degradation (Stedmon and Markager, 2005b). F1 has also been related to protein-like fluorescence of extracellular polymeric substances (Liu and Fang, 2002). Fluorescence intensities of F1 were the lowest compared to the other fluorophores, but significantly higher in the SML compared to the ULW (Mann-Whitney rank sum test, $p<0.001$, $n=38$ ). Both in SML and ULW, fluorescence intensities of F1 were positively correlated to components F3, F4 and F5 (Spearman rank order correlation coefficient $C=0.37$, $p<0.001, n=76$ with F3; $C=0.41, p=0.001, n=57$ with F4; $C=0.38, p<0.001, n=76$ with F5).

Component F2 had a short wavelength excitation range (250-260 nm) with emission at longer wavelengths (500$520 \mathrm{~nm}$ ), corresponding to peak A of fulvic acids and humic acids (Stedmon and Markager, 2005a; Singh et al., 2010; Yamashita and Jaffé, 2008; Coble, 2007; Santín et al., 2009). F2 showed a regional enrichment in the SML, with highest values at the northernmost stations S2 to S3 and at stations S10_1 to S10_4 (Fig. 7). F2 enrichment was not ubiquitous (Fig. 8), with median $\mathrm{EF}=1$, ranging from a minimum $\mathrm{EF}=0.5$ and a maximum $\mathrm{EF}=3.6 . \mathrm{F} 2$ positively correlated with bacterial abundance and temperature (Table 4) and to F3 and F5 components (Spearman rank order correlation coefficient $C=0.74, p<0.001, n=76$ with F3, and $C=0.71$, $p<0.001, n=76$ with F5).

Component F3 was characterized by a clear excitation peak at $265 \mathrm{~nm}$, with emission maxima in the longer wavelength range $520-540 \mathrm{~nm}$. Component $\mathrm{F} 3$ showed a median $\mathrm{EF}=1.1$ (minimum $\mathrm{EF}=0.3$, maximum $\mathrm{EF}=4.7$ ), indicating a slight enrichment in the SML (Fig. 8), with higher accumulations close to the coast at stations S19_2 to S1778 and at the edge of the continental shelf at stations S4 and S8 (Fig. 7), in correspondence with the highest enrichment of gel particles in the SML (Engel and Galgani, 2016). In our study F3 was positively correlated with the abundance of bacteria, proteinaceous particles and increasing $\mathrm{SUVA}_{254}$ (Table 4). It showed an inverse correlation to salinity (Table 4). Besides F1 and F2, F3 was significantly correlated to F5 (Spearman rank order correlation coefficient $C=0.87$, $p<0.001, n=76$ ).

Component F4 was not detectable at all stations, but showed high enrichment in the SML close to the coast and along the continental shelf at stations S10_1 to S10_4, S13_1 to S13_3, S14_1 to S15_2 (Fig. 7). F4 was generally enriched in the SML (Fig. 8) with median $\mathrm{EF}=1.5$ (in a minimum-maximum EF range of 0.4-14.9) and with significant differences in fluorescence intensity compared to the ULW (Mann-Whitney rank sum test, $p<0.001, n=38$ ). F4 featured characteristics of an amino-acid-like fluorophore with excitation-emission maxima in the range 250-265/284320 in the fluorescence peak $T$ region of tyrosine (Coble, 1996; Murphy et al., 2008; Aoki et al., 2008; Yamashita and Tanoue, 2003) and phenylalanine (Yamashita and Tanoue, 2003; Jørgensen et al., 2011) (Table 3). F4 was negatively correlated to bacterial abundance (Table 4), and to slope ratio SR with $\mathrm{SR}=(S(275-295): S(350: 400))$. F4 was also negatively correlated to SMHIX, indicating a low humic-acid content of this fluorophore. As for F1, it positively correlated with $\mathrm{SUVA}_{254}$ and DHAA\%-DOC (Table 4). Interest- 

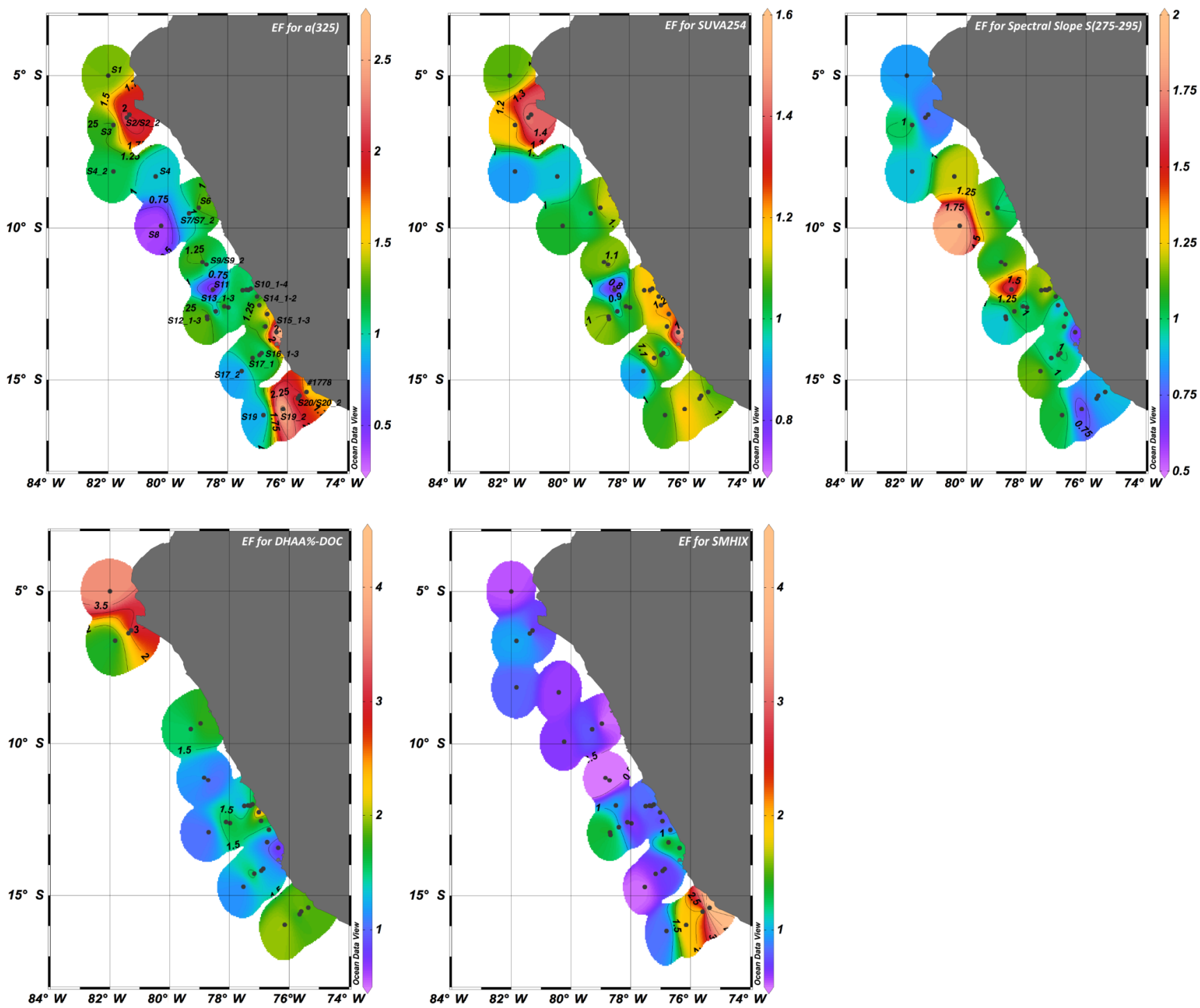

Figure 5. Enrichment factors (EFs) in the Peruvian upwelling region. From the top left, EF for absorption coefficient measured at $325 \mathrm{~nm}$ both in SML and ULW, spectral slope parameter $S(275-295)$ as indicator for changes in DOM molecular weight, SUVA 254 as indicator for DOM aromatic content, DHAA\%-DOC as indicator of DOM lability, and SMHIX as indicator of humic content of DOM.

ingly, F4 showed the highest fluorescence intensities among all samples.

Component F5 was quite difficult to identify, as we found no comparable spectra in the literature. It showed typical characteristics of allochtonous humic-like material with excitation/emission ranges in the peak $\mathrm{A}$ and $\mathrm{C}$ regions, which have been observed in bay and offshore waters (Mostofa et al., 2013). F5 had the highest fluorescence intensities both in the SML and ULW but was not clearly enriched in one or the other compartment (Fig. 8). EFs ranged from a minimum of 0.5 and a maximum of 3 , with median value $=1.1$. Highest enrichments in the SML were observed at northern stations S4 and S4_2, at stations S10_1 to S10_4, and in the southern stations S20 to S1778 (Fig. 7). F5 was similar in charac- teristics to component $\mathrm{F} 3$, and positively correlated to bacterial abundance and proteinaceous CSP particles (Table 4). Component F5 was also positively correlated to all other fluorophores F1, F2, F3 as described, and to F4 (Spearman rank order correlation coefficient $C=0.34, p=0.009, n=57$ ).

On the revisited stations, only component F1 showed a direct dependency on light exposure, significantly decreasing in fluorescence - thus concentration - with increasing global radiation intensity $\left(r^{2}=0.56, p=0.013, n=10\right)$. Components F2 to F5 showed no significant change with increased irradiation (Spearmank rank order correlation analysis). 

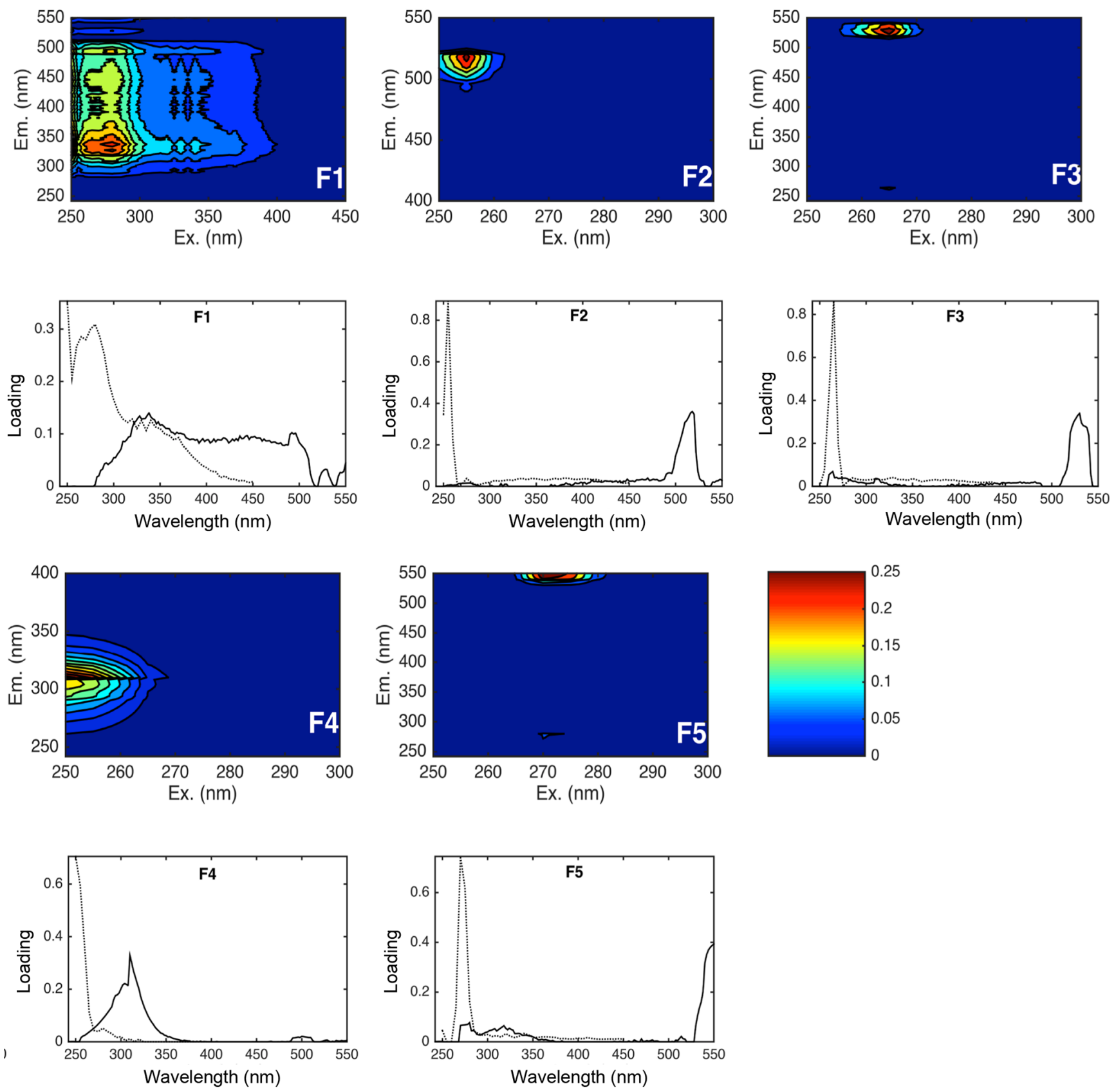

Figure 6. (Above) Contour plots of five fluorescent components as identified by PARAFAC analysis and (below) relative spectral loadings of overlaid spectra for the 5-components model validated with 3 split comparisons. The axes of contour plots have been scaled to better visualize the fluorescence intensities (R.U.). A figure with the complete spectrum is included in the Supplement (Fig. S3). The dashed black line in the spectral loadings indicates excitation maxima for each component, the solid black line indicates emission peaks.

\subsection{Changes in CDOM properties related to the biological and physical environment}

Both in the SML and ULW, CDOM optical properties as absorption coefficient $a(325), S(275-295)$, and $\mathrm{SUVA}_{254}$ were compared to salinity, temperature, wind speed and particulate organic carbon (POC) (Table 5). Data on POC have been described in detail in Engel and Galgani (2016). CDOM absorption coefficient $a(325)$ decreased at higher salinity, temperature and wind speed in the SML and ULW, with stronger dependency on these physical parameters in the SML (Table 5). In both compartments, there was a positive correlation of $a(325)$ to POC. The spectral slope parameter $S$ (275-295), indicator for DOM molecular weight, source, and degra- 
Table 4. Spearman rank order correlation coefficients $(C)$ between fluorescent components $(\mathrm{F} 1-5)$ and total bacterial and phytoplankton cells, TEP and CSP particles, SUVA $254, S(275-295)$, SR, $a(325)$, DHAA\%-DOC, SMHIX, salinity and temperature measured in our study, both in the SML and ULW. Statistical significance was accepted for $p<0.05 . n=$ number of samples. Only statistically significant correlations are shown. Bold characters indicate negative correlations.

\begin{tabular}{|c|c|c|c|c|c|c|c|c|c|c|c|c|c|}
\hline $\begin{array}{l}\text { Component } \\
\text { [R.U.] }\end{array}$ & Statistics & $\begin{array}{r}\text { Bacteria } \\
\left.\text { [cells } \mathrm{mL}^{-1}\right]\end{array}$ & $\begin{array}{r}\text { Phytoplankton } \\
\text { [cells } \mathrm{mL}^{-1} \text { ] }\end{array}$ & $\begin{array}{r}\text { TEP } \\
{\left[\mathrm{L}^{-1}\right]}\end{array}$ & $\begin{array}{r}\text { CSP } \\
{\left[\mathrm{L}^{-1}\right]}\end{array}$ & $\begin{array}{r}\text { SUVA }_{254} \\
{\left[\mathrm{mg} \mathrm{C} \mathrm{L}^{-1} \mathrm{~m}^{-1}\right]}\end{array}$ & $\begin{array}{r}S(275-295) \\
{\left[\mathrm{nm}^{-1}\right]}\end{array}$ & SR & $\begin{array}{l}a(325) \\
{\left[\mathrm{m}^{-1}\right]}\end{array}$ & $\begin{array}{r}\text { DHAA\%-DOC } \\
{[\%]}\end{array}$ & SMHIX & $\begin{array}{r}\text { Salinity } \\
\text { [psu] }\end{array}$ & $\begin{array}{r}\text { Temperature } \\
{\left[{ }^{\circ} \mathrm{C}\right]}\end{array}$ \\
\hline \multirow[t]{3}{*}{$\mathrm{F} 1$} & $C$ & & 0.285 & 0.281 & & 0.620 & -0.257 & -0.387 & 0.406 & 0.696 & -0.342 & -0.261 & -0.323 \\
\hline & $p$ & & 0.031 & 0.014 & & $<0.001$ & 0.025 & $<0.001$ & $<0.001$ & $<0.001$ & 0.003 & 0.023 & 0.004 \\
\hline & $n$ & & 57 & 76 & & 76 & 76 & 75 & 76 & 76 & 76 & 76 & 76 \\
\hline \multirow[t]{3}{*}{$\mathrm{F} 2$} & $C$ & 0.393 & & & & & & & & & 0.225 & & 0.238 \\
\hline & $p$ & $<0.001$ & & & & & & & & & 0.050 & & 0.038 \\
\hline & $n$ & 71 & & & & & & & & & 76 & & 76 \\
\hline \multirow[t]{3}{*}{ F3 } & $C$ & 0.355 & & & 0.411 & 0.305 & -0.221 & -0.226 & & & & -0.273 & \\
\hline & $p$ & 0.002 & & & $<0.001$ & 0.007 & 0.055 & 0.051 & & & & 0.017 & \\
\hline & $n$ & 71 & & & 76 & 76 & 76 & 76 & & & & 76 & \\
\hline \multirow[t]{3}{*}{$\mathrm{F} 4$} & $C$ & -0.409 & & & & 0.346 & & -0.410 & & 0.392 & -0.536 & & \\
\hline & $p$ & 0.003 & & & & 0.008 & & 0.002 & & 0.008 & $<0.001$ & & \\
\hline & $n$ & 52 & & & & 56 & & 56 & & 56 & 57 & & \\
\hline \multirow[t]{3}{*}{ F5 } & $C$ & 0.270 & & & 0.402 & & & & & & & & \\
\hline & $p$ & 0.023 & & & $<0.001$ & & & & & & & & \\
\hline & $n$ & 71 & & & 76 & & & & & & & & \\
\hline
\end{tabular}

dation processes (Helms et al., 2008), increased at higher salinity and temperature (Fig. 9d) in the SML and ULW. It did not show any correlation to wind speed, but a significant negative correlation to POC in both compartments (Table 5). Moreover, an increase of bacterial and phytoplankton cells led to a lower $S(275-295)$ both in the SML and ULW (Fig. 9a, b). The dependency of $S(275-295)$ on bacteria in the SML (Spearman rank order correlation coefficient $C=-0.59, p<0.001, n=35)$ was stronger than in the ULW $(C=-0.38, p=0.02, n=36)$, potentially indicating a higher bacterial CDOM contribution. S(275-295) was also negatively correlated to phytoplankton abundance with a stronger relationship in the ULW $(C=-0.64, p=0.001$, $n=22)$ than in the SML $(C=-0.47, p=0.004, n=35)$. In the SML, we observed a significant decrease in $S(275-295)$ with increasing abundance of gelatinous proteinaceous particles (CSP) (Fig. 9c), while in the underlying water a lower $S(275-295)$ was highly related to increasing concentration of polysaccharidic gels (TEP). In both SML and ULW, higher salinity, temperature and wind speed were related to lower $\mathrm{SUVA}_{254}$ indexes, as indicators of DOM aromaticity. A positive correlation was observed instead between $\mathrm{SUVA}_{254}$ and POC (Table 5). An increment in temperature was inversely correlated to DOM lability, and therefore bioavailability, expressed as DHAA\%-DOC, indicating a higher degree of DOM degradation (Spearman rank order correlation coefficient $C=-0.68, p<0.001, n=29$ in the SML and $C=$ $-0.66, p<0.001, n=29$ in the ULW). DHAA\%-DOC was also lower at higher salinity (Spearman rank order correlation coefficient $C=-0.42, p=0.02, n=29$ in the SML and $C=-0.63, p<0.001, n=29$ in the ULW). As for $S(275-$ 295), we observed similar trends in SR (data not shown): SR was negatively correlated to DHAA\%-DOC (Spearman rank order correlation coefficient $C=-0.50, p<0.001, n=75$ ) and to both gel particles abundance (Spearman rank order
Table 5. Spearman rank order correlation $(C)$ between CDOM optical properties both in the SML and ULW with salinity $\left(C_{\mathrm{PSU}}\right)$, water temperature $\left(C_{T}\right)$, wind speed $\left(C_{U}\right)$ and particulate organic carbon $\left(C_{\mathrm{POC}}\right)$. Significant correlations $(p<0.01)$ are marked in bold (except ${ }^{\mathrm{a}}=p<0.05$ ). $n$ is the number of samples, except ${ }^{*}=36$ samples.

\begin{tabular}{lrrrrr}
\hline SML & $C_{\text {PSU }}$ & $C_{T}$ & $C_{U}$ & $C_{\text {POC }}$ & $n$ \\
\hline CDOM $a(325)$ & $-\mathbf{0 . 4 2 0}$ & $-\mathbf{0 . 7 2 8}$ & $-\mathbf{0 . 5 3 5}$ & $\mathbf{0 . 5 7 9}$ & 38 \\
$S(275-295)$ & $\mathbf{0 . 6 4 0}$ & $\mathbf{0 . 6 1 6}$ & 0.318 & $-\mathbf{0 . 5 9 7}$ & 38 \\
SUVA $_{254}$ & $-\mathbf{0 . 3 8 0}^{\text {a }}$ & $-\mathbf{0 . 6 3 4}$ & $-\mathbf{0 . 4 6 0}$ & $\mathbf{0 . 5 3 7}$ & 38 \\
\hline ULW & & & & & \\
\hline CDOM $a(325)$ & $-\mathbf{0 . 3 2 9}^{\text {a }}$ & $-\mathbf{0 . 6 3 7}$ & $-\mathbf{0 . 3 8 6}^{\mathrm{a}}$ & $\mathbf{0 . 6 5 6}^{*}$ & 38 \\
S(275-295) & $\mathbf{0 . 4 9 3}$ & $\mathbf{0 . 6 1 3}$ & 0.24 & $-\mathbf{0 . 6 2 2}^{*}$ & 38 \\
SUVA $_{254}$ & $-\mathbf{0 . 3 2 6}^{\text {a }}$ & $-\mathbf{0 . 4 5 8}$ & $-\mathbf{0 . 3 2 4}^{\mathrm{a}}$ & $\mathbf{0 . 4 9 5}^{*}$ & 38 \\
\hline
\end{tabular}

correlation coefficient $C=-0.37, p<0.001, n=75$ for TEP and $C=-0.33, p=0.004, n=75$ for CSP). SR did not show any significant correlation to total bacteria or phytoplankton abundance, but was significantly lower in the SML, with a median $\mathrm{EF}=0.9$ (Mann-Whitney rank sum test, $p=0.013, n=38$ ). Furthermore, DHAA\%-DOC was significantly higher in the SML (Mann-Whitney rank sum test, $p=0.036, n=38$ ).

\section{Discussion}

\subsection{CDOM enrichment and production in the top surface layer of the ocean}

The enrichment of organic material in the SML has been mainly related to biological processes in the euphotic zone below the surface (Hardy, 1982; Liss and Duce, 2005). EBUS 

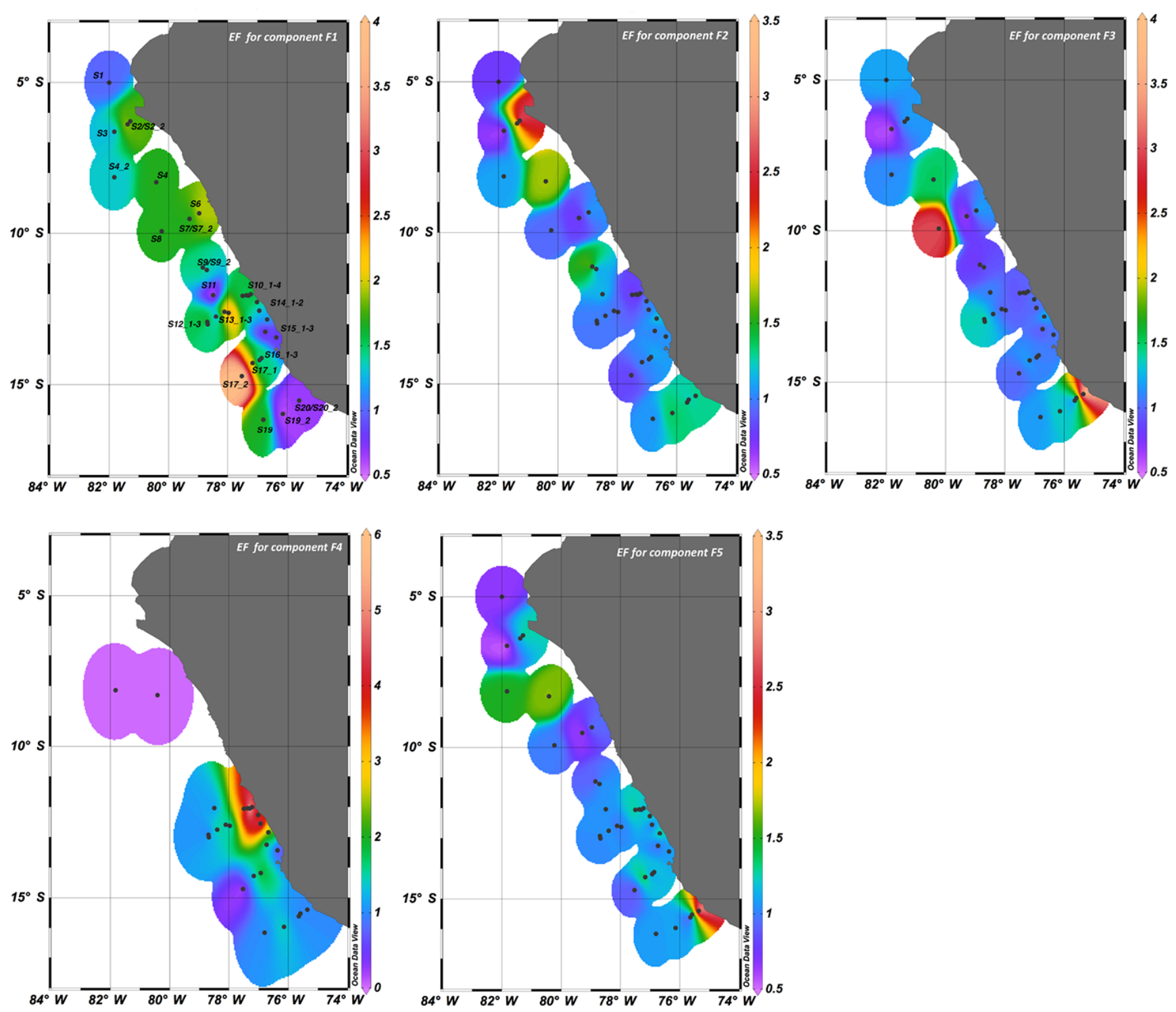

Figure 7. Distribution of enrichment factors (EFs) for fluorescent components F1, F2, F3, F4, F5 identified in this study. Maximum EF for F4 has been recorded at station S10_2, with a value of 14.9. For visualization purposes, this data point is not included in the figure and fluorescence intensities have been scaled down to a maximum $\mathrm{EF}=6$.

are among the most productive regions in the ocean and therefore interesting systems to investigate the relationship between organic matter accumulation and SML biogeochemical properties. The Peruvian EBUS is associated with an extensive OMZ and a key region for the study of gas fluxes from the ocean (Paulmier et al., 2008; Paulmier and Ruiz-Pino, 2009; Keeling et al., 2010). The presence of an organicsenriched surface layer may strongly affect gas exchange between the marine and the atmospheric systems (Engel and Galgani, 2016). The characterization of CDOM via its optical properties adds relevant information to the organic matter composition in the SML, as it allows discriminating between terrestrial and marine sources of DOM that may be equally enriched at the surface. Moreover, it helps tracking changes in DOM "quality" deriving from higher DOM exposure to solar radiation at the sea surface than deeper in the water column. As such, microbial and photochemical DOM turnover in the SML may contribute to the atmospheric emission of gases and chemical reactive species, and interfere with the microbial carbon loop in the ocean.

In the Peruvian EBUS, we observed a general enrichment of CDOM in the SML with respect to the ULW, based on values of the specific absorption coefficient $a(\lambda)$ measured at $325 \mathrm{~nm}$. Higher values for CDOM absorbance were observed in the coastal upwelling stations characterized by lowest salinity, temperature and highest enrichment of organic 


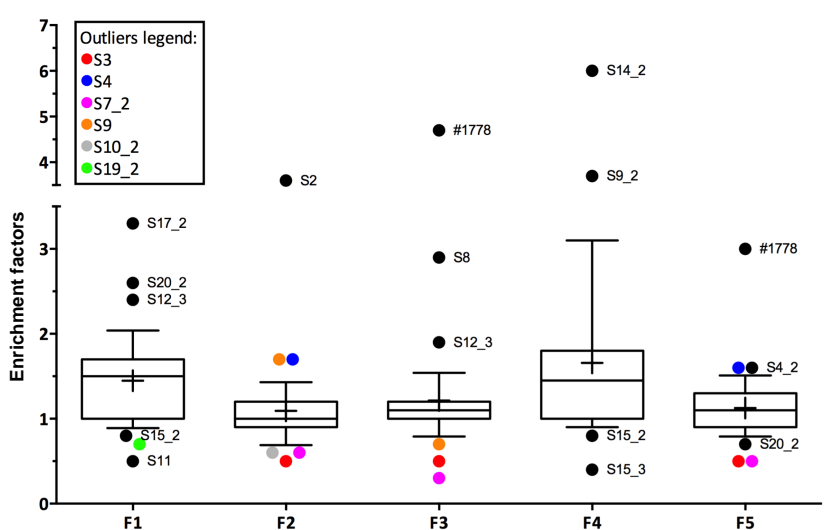

Figure 8. Box and Whiskers plot of enrichment factors for fluorescent components F1, F2, F3, F4 and F5. The horizontal lines of the boxes represent $25 \%, 50 \%$ (median) and $75 \%$ percentiles (from bottom to top). In the boxes, crosses represent the mean. Whiskers represent minimum and maximum values, and circles are outliers. Outliers are staggered to better visualize them. To identify the station, see outliers' labels and color legend. For F4, $n=24$. For all other components, $n=38$.

components, both in the particulate and dissolved fraction (Engel and Galgani, 2016). It is commonly observed that spectral loadings of allochtonous/terrestrial-like CDOM decrease with increasing salinity (Murphy et al., 2008). However, we did not observe such trends in our samples. Instead, we found a negative correlation of amino-acid-like fluorophore F1 to salinity and temperature, and no clear enrichment of humic-acid-like fluorophores F2, F3 and F5 in the SML. Therefore, we think that in the SML of the study region the contribution of terrestrially derived CDOM, if any, is overwhelmed by the high productivity of the upwelling system. Organics enriched in the SML such as the aminoacidic compounds $\mathrm{F} 1$ and $\mathrm{F} 4$ found at the upwelling stations may therefore reflect other processes rather than input of allochtonous CDOM from land. DOC concentrations in the SML were related to DOC concentrations in the ULW (Engel and Galgani, 2016), and the same was true for CDOM absorption coefficient $a(325)$ (Spearman rank order correlation coefficient $C=0.82, p<0.001, n=38$ ), implying a direct dependency of SML CDOM on the organic matter in the ULW (Zhang and Yang, 2013). CDOM absorption coefficient $a(325)$ as well as its spectral slope $S(275-295)$ did not show any correlation to changes in DOC concentrations, neither in the SML, nor in the ULW, but were significantly related to DOM diagenesis (DHAA\%-DOC) POC, and abundance of autotrophic and heterotrophic microorganisms suggesting a recent production of labile or semi-labile substrates driven by in situ microbial or photochemical processes in the underlying euphotic zone or at the immediate sea surface. A closer look on CDOM spectral properties revealed significant differences between SML and ULW. According to Helms et al. (2008), an increase in $S(275-295)$ and SR
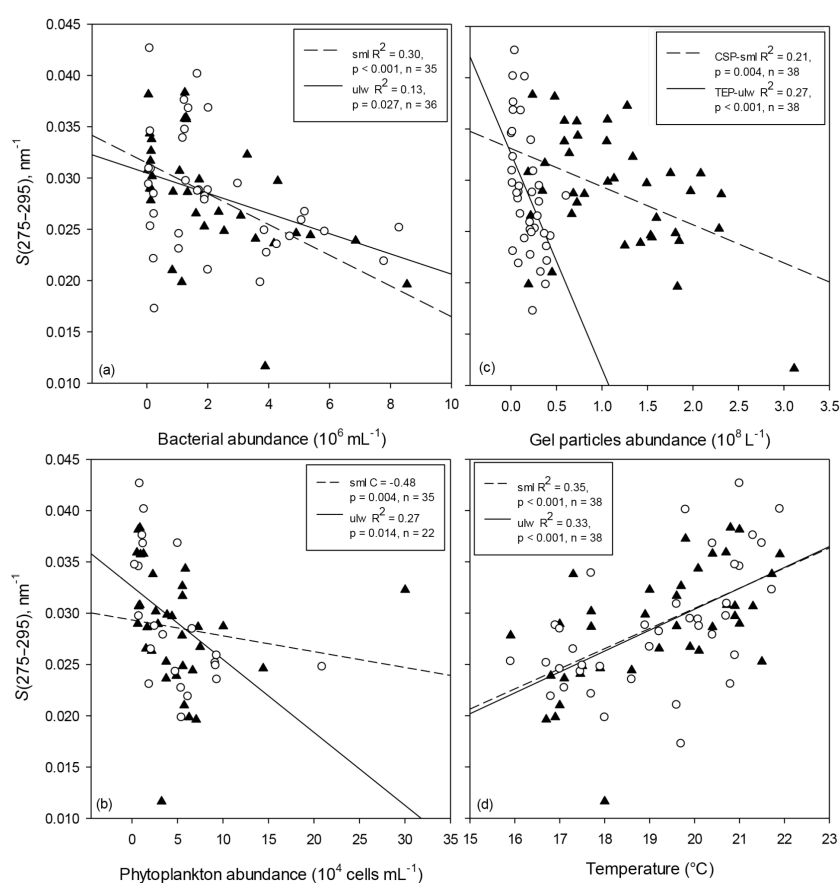

Figure 9. (a) Linear regression between bacterial abundance $\left[10^{6}\right.$ cells $\left.\mathrm{mL}^{-1}\right]$ and spectral slope $S(275-295)\left[\mathrm{nm}^{-1}\right]$ in SML and ULW. (b) Linear regression (ULW) and Spearman rank order correlation (SML) between phytoplankton abundance $\left[10^{4}\right.$ cells $\left.\mathrm{mL}^{-1}\right]$ and spectral slope $S(275-295)\left[\mathrm{nm}^{-1}\right]$. (c) Linear regression between CSP abundance $\left[10^{8}\right.$ particles $\left.\mathrm{L}^{-1}\right]$ and spectral slope $S(275-295)\left[\mathrm{nm}^{-1}\right]$ in the SML and between TEP abundance $\left[10^{8}\right.$ particles $\left.\mathrm{L}^{-1}\right]$ and spectral slope $S(275-295)\left[\mathrm{nm}^{-1}\right]$ in the ULW. (d) Linear regression between temperature $\left[{ }^{\circ} \mathrm{C}\right]$ and $S(275-$ 295) $\left[\mathrm{nm}^{-1}\right]$ in SML and ULW. Black triangles: SML, open dots: ULW.

suggests CDOM photodegradation and decreasing molecular weight. DHAA\%-DOC is used here as an indicator for DOM diagenesis, thus, the extent of microbially altered DOM. The higher DHAA\%-DOC, the more labile, bioavailable, recent and less altered DOM in the sample. We observed a negative correlation when comparing DHAA\%-DOC and POC to $S(275-295)$ and to SR. The higher DHAA\%-DOC, the lower S(275-295) and SR. Microorganisms adopt several strategies against tough environments; the correlation between DHAA\%-DOC to $S(275-295)$ and SR was stronger in the SML than in the ULW, suggesting an accumulation of HMW-DOM related to the contribution of microorganisms directly in the SML or in the proximity due to cell lysis or exudation, which has been previously proposed (Tilstone et al., 2010). Thus, the close correlations of optical parameters to POC and marine gels lead to hypothesize that autochthonous $\mathrm{CDOM}$ produced in the very surface ocean can actually be incorporated in the gelatinous organic carbon pool. 


\subsection{CDOM composition}

The analysis of EEMs allowed the identification of five fluorescent components both in the SML and ULW, of which two (F1 and F4) showed an amino-acid-like fluorescence of autochthonous material, and three (F2, F3 and F5) had the characteristics of fulvic-acid-like or humic-acid-like CDOM (Table 3). These classes of fluorophores are commonly found in marine environments (Coble, 2007; Mostofa et al., 2013), but EEMs analyses of SML samples are scarce and up to now revealed the enrichment in humic-acid-like fluorophores only (Zhang and Yang, 2013). Phenolic materials deriving from humic and fulvic acids transported by river drainage, and from macroalgae polyphenols, are often enriched in the SML, and indicate the presence of surface slicks (Carlson, 1982; Carlson and Mayer, 1980). Here, we observed a significant enrichment of amino-acid-like fluorophores F1 and F4 with respect to ULW, in good accordance with previous reports on amino acids enrichment in the SML (Kuznetsova et al., 2004; Cunliffe et al., 2013; Tilstone et al., 2010), and with our own observations for the Peruvian EBUS (Engel and Galgani, 2016). F1 has shown the greatest production rates during algal blooms, whereas its major sinks are UV light and microbial degradation (Stedmon and Markager, 2005b). Moreover, it is assumed that F1 relates to the fluorescence of amino acids still bound in the proteinaceous matrix (Stedmon and Markager, 2005b). Based on these previous findings and on our results (Table 4), we suggest that F1 is a tryptophanlike fluorophore, originating by in situ primary production, relatively labile as it features an increase in fluorescence intensity correlated to increasing DHAA\%-DOC, and possibly included in the gel particles surface matrix. F4 showed very high fluorescence intensities compared to F1, F2 and F3. In the literature, F4 has been associated to the fluorescence of amino acids in peptides (Stedmon and Markager, 2005b). Similarly to F1, F4 showed a positive correlation to DHAA\%-DOC, as to indicate its labile nature. The aromatic content of DOM is highly responsible for its photoreactivity (e.g., Mopper et al., 2014); F4 correlation to DOM lability (DHAA\%-DOC) and aromatic content $\left(\mathrm{SUVA}_{254}\right)$ was weaker than for F1. In our study, this may indicate F4 as an intermediate product of photochemically driven aggregation or microbial degradation of labile CDOM. F4 has been linked to the fluorescence of tyrosine and phenylalanine (e.g., Coble, 1996; Murphy et al., 2008; Jørgensen et al., 2011) and both amino acids were enriched in the SML of the Peruvian EBUS (Engel and Galgani, 2016). Recently, Cao et al. (2014) performed a laboratory study aimed at understanding intermolecular interactions between $\mathrm{N}_{2} \mathrm{O}$ and phenol $\left(\mathrm{C}_{6} \mathrm{H}_{5} \mathrm{OH}\right)$, cresol $\left(\mathrm{CH}_{3} \mathrm{C}_{6} \mathrm{H}_{4} \mathrm{OH}\right)$, and toluene $\left(\mathrm{CH}_{3} \mathrm{C}_{6} \mathrm{H}_{5}\right)$, which are representative aromatic compounds and useful models of various biomolecules such as the aromatic amino acids tyrosine and phenylalanine containing a benzene ring. Their experiment was carried out in a $\mathrm{Ne}$ matrix at about $8 \mathrm{~K}$ $\left(-265.15^{\circ} \mathrm{C}\right)$ with millimolar concentrations of the aromatic compounds (Cao et al., 2014), therefore in a setting not at all comparable to our experimental setup. Cao and colleagues found interesting $\pi$ non-covalent interactions between $\mathrm{N}_{2} \mathrm{O}$ and the aromatic compounds, suggesting an interaction of $\mathrm{N}_{2} \mathrm{O}$ with tyrosine and phenylalanine of great interest for biological processes. We mention it here, as the presence of these specific amino acids in the SML of the Peruvian EBUS may interfere with the exchange of $\mathrm{N}_{2} \mathrm{O}$ between the ocean and the atmosphere, as suggested previously (Engel and Galgani, 2016). The enrichment of fluorophores F1 and F4 in the SML could be partly due to the upwelling of colder nutrientrich waters that boost primary production in the euphotic zone. Salinity and temperature gradients may thus explain the variation of F1 in the SML (Table 4), reflecting local upwelling and DOM production. The observed accumulation of amino-acid-like CDOM may additionally derive from a local microbial release within the SML itself due to cell disintegration, or as protection strategy for the exposure to UV light in a demanding environment (Ortega-Retuerta et al., 2009). Mycosporine-like amino acids (MAAs), for example, serve as a natural microbial UV sunscreen against photodamage (Garcia-Pichel et al., 1993) and have been observed in enriched concentrations in the SML (Tilstone et al., 2010). Major losses of autochthonous protein-like fluorophores in the SML may be related to photochemical and microbial degradation: negative correlations of F1 and F4 to SR may hint to photochemical degradation, recalling that an increase in SR is usually related to photobleached material (Helms et al., 2008). The negative correlation of F4 to bacterial abundance may be instead an indication of a microbial sink of this fluorophore.

The fulvic-acid or humic-acid-like components F2, F3 and F5 were ubiquitous in SML and ULW, with no significant differences in fluorescence intensities between the two compartments. F2 and F3 have been previously observed in coastal marine environments (e.g., Jørgensen et al., 2011; Ishii and Boyer, 2012). In the literature, component F2 has been characterized as of terrestrial origin, allochthonous in marine environments, found in bays, rivers and coastal waters. It is assumed to reflect small-sized molecules, being resistant to photodegradation, biologically not available, and mainly derived from photobleached terrestrial-like humic acids in marine waters with highest concentrations near the surface (Ishii and Boyer, 2012). In this study we did not find a correlation of $\mathrm{F} 2$ to global radiation but a positive correlation to temperature and to bacterial abundance (Table 4). We also observed an increase of bacterial abundance with increasing sea-surface temperature, which is well supported by existing literature (e.g., Morán et al., 2015). Higher temperature also stimulates the activity of marine bacteria (e.g., Piontek et al., 2009). Thus, as F2 probably reflects the fluorescence of highly degraded small molecules, we may characterize F2 as the ultimate product of microbial CDOM degradation in the surface ocean: no longer bioavailable anymore. F3-like fluorophores have been identified as an intermediate product 
of terrestrially derived DOM, still subject to further photochemical degradation (Stedmon et al., 2007). Earlier studies attributed this optical behavior to fulvic acid C-like components showing a peak in region A. According to Ishii and Boyer (2012), F3 like components may comprise larger hydrophobic molecules that are photodegradable by UV light, of terrestrial or microbial origin, biologically degraded and produced. Moreover, F3 appearance has been related to apparent oxygen utilization (Yamashita et al., 2010), further suggesting a microbial source of this material (Jørgensen et al., 2011). In this study, F3 showed a slight enrichment in the SML and was related to heterotrophic bacteria as well as to CSP particles, possibly indicating its origin in microbial reworking of larger organic compounds. F5 showed characteristics of humic acid fluorophores, with fluorescence maximum ranges to the lower end of $\mathrm{F} 3$ emission indicating a more pronounced CDOM alteration with respect to F3. Showing similar correlations to heterotrophic bacteria and CSP, F5 may as well derive from a microbial in situ reworking of larger organic molecules both in the SML and ULW contributing to the size continuum and reactivity of the gel particles pool in surface waters. In fact, a net production and accumulation of humic-like CDOM in surface waters may occur in upwelling regions (Nieto-Cid et al., 2005; Jørgensen et al., 2011), whereas photochemical loss is thought to be the major removal mechanism of this material (e.g., Mopper and Schultz, 1993). In this study, fulvic-acid-/humic-acidlike fluorophores correlated well among each other, suggesting a common underlying origin.

Based on CDOM absorption and fluorescence characteristics, we propose a conceptual model for the control of CDOM production and loss in the SML and ULW by microbial and photochemical processes (Fig. 1). In this model, the accumulation of CDOM in the SML is the result of (a) the biological production of CDOM in the ULW and deeper water column, stimulated by the upwelling of nutrient-rich waters to the sunlit surface and (b) the local microbial release of CDOM as a response to elevated solar radiation. Previous and our own observations on amino-acid fluorophores (F1, F4), as well as on the enrichment of CSP and amino acids in the SML described elsewhere (Engel and Galgani, 2016), suggest a rapid turnover of fresh DOM in the sea surface itself. On one hand, microbes release fresh DOM directly within the SML or in the upper first centimeters, as a consequence of high light exposure. On the other hand, and both in the SML and ULW, microbial and photochemical degradation would lead to the loss of amino-acid-like fluorophores (F1, F4) and to the accumulation of less labile and humiclike components completely degraded (F2) or still subject to further photochemical degradation (F3, F5).

\subsection{Implications for surface ocean dynamics and future perspectives}

Optical properties of DOM in the Peruvian EBUS revealed a SML characterized by amino-acid-like CDOM fluorophores. CDOM enrichment in the SML has been observed in different marine regions associated with enrichment in phenolic compounds, MAAs and humic acids (Carlson, 1982; Carlson and Mayer, 1980; Tilstone et al., 2010; Zhang and Yang, 2013). MAAs for example (LMW-DOM) are well known as microbial sunscreen in aquatic environments (Bhatia et al., 2011; Shick and Dunlap, 2002), and were observed in higher concentrations in the SML during surface slicks development (Tilstone et al., 2010). Here, the accumulation of amino-acidlike CDOM may have a major microbial source directly in the SML or the immediate subsurface water, whereas fulvicacid-/humic-acid-like CDOM likely originated in the sunlit zone below by microbial and photochemical processing of upwelled organic material. Accumulation of amino acids in the SML has been related to a reduced bacterial activity, being the SML an extreme environment where the consumption of amino acids may be lower (Santos et al., 2012). A reduced bacterial activity may thus also explain the amino acids enrichment in the SML of the Peruvian EBUS (Engel and Galgani, 2016). We may assume that in the top layer of the ocean, and at higher extent in the SML, exposure to light may have determined three main processes: (1) microbial release of amino-acid-like CDOM as a sunscreen function, (2) increased availability of biological substrate by CDOM photolysis and (3) further photochemical degradation of microbially altered CDOM. Photochemistry is able to alter the HMW fraction making it more available for microbial attack (Kieber et al., 1989), but at the same time it may lead to a net loss of bioavailable substrates (Kieber, 2000). Therefore, the interplay of photochemistry and microbial activity controls the accumulation and loss of organic compounds at the sea surface, implying consequences on gas fluxes worth deeper investigations in climate-relevant marine regions such as the OMZ off the coast of Peru. As an example, high microbial DOM respiration can lead to higher production of $\mathrm{CO}_{2}$ in the SML (Garabétian, 1990), whereas high concentrations of isoprene may be released from photosensitized DOM reactions in the SML, proving an abiotic source of this gas uncoupled from biological production (Ciuraru et al., 2015).

It remains unclear whether in the Peruvian EBUS an increase in bioavailable carbon may have implied a higher heterotrophic respiration and $\mathrm{CO}_{2}$ production in the SML, and this is an attractive hypothesis for future studies in this direction. It may be suggested however, that a net DOM production in the SML may take place independently of the biological productivity of the underlying waters as a sole microbial response to light exposure. We assessed the enrichment of light-absorbing proteinaceous organic material in the SML of a highly productive oceanic system, which may interfere with correct estimates of primary production from remote 
measurements. To conclude, we suggest that further primary production estimates take into account the CDOM enrichment in the first centimeters of the ocean.

\section{The Supplement related to this article is available online at doi:10.5194/bg-13-2453-2016-supplement.}

Acknowledgements. We would like to thank the captain and the crew of R/V Meteor during M91 cruise for the logistic support during the zodiac samplings. We also would like to thank $\mathrm{H}$. Bange as chief scientist and all the scientific crew, in particular J. Roa for sampling and analysis on board and for DOC analysis back at the institute. We are very grateful to R. Flerus and T. Klüver for amino-acids measurements and flow cytometry, respectively, and to S. Manandhar and N. Bijma for microscopy analysis. The authors would like to thank K. Murphy and A. Loginova for help in DrEEE troubleshooting and the three anonymous referees for valuable suggestions in revising this manuscript. This study has been supported by BMBF SOPRAN II and III (Surface Ocean Processes in the Anthropocene, 03F0611C-TP01 and 03F0662A-TP2.2).

The article processing charges for this open-access

publication were covered by a Research

Centre of the Helmholtz Association.

Edited by: H. Bange

\section{References}

Amon, R. M. W. and Fitznar, H. P.: Linkages among the bioreactivity, chemical composition, and diagenetic state of marine dissolved organic matter, Limnol. Oceanogr., 42, 287-297, 2001.

Aoki, S., Ohara, S., Kimura, K., Mizuguchi, H., Fuse, Y., and Yamada, E.: Characterization of Dissolved Organic Matter Released from Microcystis aeruginosa, Anal. Sci., 24, 389-394, doi:10.2116/analsci.24.389, 2008.

Arístegui, J., Barton, E. D., Tett, P., Montero, M. F., GarcíaMuñoz, M., Basterretxea, G., Cussatlegras, A.-S., Ojeda, A., and de Armas, D.: Variability in plankton community structure, metabolism, and vertical carbon fluxes along an upwelling filament (Cape Juby, NW Africa), Prog. Oceanogr., 62, 95-113, doi:10.1016/j.pocean.2004.07.004, 2004.

Bange, H. W.: Surface Ocean - Lower Atmosphere Study (SOLAS) in the upwelling region off the coast of Peru, Cruise No. M91, 126 December 2012, Callao (Peru), Bremen, 69 pp., 2013.

Bange, H. W., Rapsomanikis, S., and Andreae, M. O.: Nitrous oxide cycling in the Arabian Sea, J. Geophys. Res-Oceans, 106, 1053 1065, doi:10.1029/1999jc000284, 2001.

Benner, R.: Chemical composition and reactivity, in: Biogeochemistry of marine dissolved organic matter, edited by: Hansell, D. A. and Carlson, D. J., Academic Press - Elsevier, 59-90, 2002.

Bhatia, S., Garg, A., Sharma, K., Kumar, S., Sharma, A., and Purohit, A. P.: Mycosporine and mycosporine-like amino acids: A paramount tool against ultra violet irradiation, Pharmacognosy Reviews, 5, 138-146, doi:10.4103/0973-7847.91107, 2011.
Bigg, K. E., Leck, C., and Tranvik, L.: Particulates of the surface microlayer of open water in the central Arctic Ocean in summer, Mar. Chem., 91, 131-141, doi:10.1016/j.marchem.2004.06.005, 2004.

Blough, N. V.: Photochemistry in the sea-surface microlayer, in: The Sea Surface and Global Change, edited by: Liss, P. S. and Duce, R. A., Cambridge University Press, 383-424, 2005.

Blough, N. V. and Del Vecchio, R.: Chromophoric DOM in the coastal environment, in: Biogeochemistry of marine dissolved organic matter, edited by: Hansell, D. A. and Carlson, D. J., Academic Press - Elsevier, 509-546, 2002.

Bopp, L., Le Quéré, C., Heimann, M., Manning, A. C., and Monfray, P.: Climate-induced oceanic oxygen fluxes: Implications for the contemporary carbon budget, Global Biogeochem. Cy., 16, 6-1-6-13, doi:10.1029/2001GB001445, 2002.

Bracchini, L., Dattilo, A. M., Falcucci, M., Hull, V., Tognazzi, A., Rossi, C., and Loiselle, S. A.: Competition for spectral irradiance between epilimnetic optically active dissolved and suspended matter and phytoplankton in the metalimnion. Consequences for limnology and chemistry, Photochem. Photobio. Sc., 10, 10001013, doi:10.1039/c0pp00291g, 2011.

Bricaud, A., Morel, A., and Prieur, L.: Absorption by dissolved organic matter of the sea (yellow substance) in the UV and visible domains, Limnol. Oceanogr., 26, 43-53, 1981.

Cao, Q., Gor, G. Y., Krogh-Jespersen, K., and Khriachtchev, L.: Non-covalent interactions of nitrous oxide with aromatic compounds: Spectroscopic and computational evidence for the formation of 1:1 complexes, J. Chem. Phys., 140, 144304, doi:10.1063/1.4870516, 2014.

Capone, D. G. and Hutchins, D. A.: Microbial biogeochemistry of coastal upwelling regimes in a changing ocean, Nat. Geosci., 6, 711-717, 2013.

Carlson, C. A.: Production and Removal Processes, in: Biogeochemistry of Marine Dissolved Organic Matter, edited by: Hansell, D. A. and Carlson, C. A., Academic Press - Elsevier, 91-150, 2002.

Carlson, D. J.: Surface microlayer phenolic enrichments indicate sea surface slicks, Nature, 296, 426-429, 1982.

Carlson, D. J. and Mayer, L. M.: Enrichment of dissolved phenolic material in the surface microlayer of coastal waters, Nature, 286, 482-483, 1980.

Chavez, F. P. and Messié, M.: A comparison of Eastern Boundary Upwelling Ecosystems, Prog. Oceanogr., 83, 80-96, doi:10.1016/j.pocean.2009.07.032, 2009.

Ciuraru, R., Fine, L., Pinxteren, M. V., D’Anna, B., Herrmann, H., and George, C.: Unravelling New Processes at Interfaces: Photochemical Isoprene Production at the Sea Surface, Environ. Sci. Technol., 49, 13199-13205, doi:10.1021/acs.est.5b02388, 2015.

Coble, P.: Characterization of marine and terrestrial DOM in seawater using excitation-emission matrix spectroscopy, Mar. Chem., 51, 325-356, 1996.

Coble, P. G.: Marine Optical Biogeochemistry: The Chemistry of Ocean Color, Chem. Rev., 107, 402-418, 2007.

Cunliffe, M., Upstill-Goddard, R. C., and Murrell, J. C.: Microbiology of aquatic surface microlayers, FEMS Microbiol. Rev., 35, 233-246, doi:10.1111/j.1574-6976.2010.00246.x, 2011.

Cunliffe, M., Engel, A., Frka, S., Gašparović , B., Guitart, C., Murrell, J. C., Salter, M., Stolle, C., Upstill-Goddard, R., and Wurl, O.: Sea surface microlayers: A unified physicochemical and bi- 
ological perspective of the air-ocean interface, Prog. Oceanogr., 109, 104-116, doi:10.1016/j.pocean.2012.08.004, 2013.

Davis, J. and Benner, R.: Quantitative estimates of labile and semilabile dissolved organic carbon in the western Arctic Ocean: A molecular approach, Limnol. Oceanogr., 52, 2434-2444, 2007.

Del Giorgio, P. A. and Duarte, C. M.: Respiration in the open ocean, Nature, 420, 379-384, 2002.

Engel, A.: Determination of Marine Gel Particles, in: Practical Guidelines for the Analysis of Seawater, edited by: Wurl, O., CRC Press, 125-142, 2009.

Engel, A. and Galgani, L.: The organic sea-surface microlayer in the upwelling region off the coast of Peru and potential implications for air-sea exchange processes, Biogeosciences, 13, 989-1007, doi:10.5194/bg-13-989-2016, 2016.

Galgani, L., Stolle, C., Endres, S., Schulz, K. G., and Engel, A.: Effects of ocean acidification on the biogenic composition of the sea-surface microlayer: Results from a mesocosm study, J. Geophys. Res.-Oceans, 119, 7911-7924, doi:10.1002/2014jc010188, 2014.

Gao, Q., Leck, C., Rauschenberg, C., and Matrai, P. A.: On the chemical dynamics of extracellular polysaccharides in the high Arctic surface microlayer, Ocean Sci., 8, 401-418, doi:10.5194/os-8-401-2012, 2012.

Garabétian, F.: Production de $\mathrm{CO}_{2}$ à l'interface air-mer, Une approche par l'étude des phénomènes respiratoires dans la microcouche de surface. $\mathrm{CO}_{2}$ Production at the Sea-Air Interface, An Approach by the Study of Respiratory Processes in Surface Microlayer, Int. Rev. Ges. Hydrobio., 75, 219-229, doi:10.1002/iroh.19900750208, 1990.

Garcia-Pichel, F., Wingard, C. E., and Castenholz, R. W.: Evidence Regarding the UV Sunscreen Role of a Mycosporine-Like Compound in the Cyanobacterium Gloeocapsa sp, Appl. Environ. Microb., 59, 170-176, 1993.

Garrett, W. D.: Collection of slick-forming materials from the sea surface, Limnol. Oceanogr., 10, 602-605, 1965.

GESAMP: The Sea-Surface Microlayer and its Role in Global Change, Reports and Studies, WMO, 1995.

Hardy, J. T.: The sea surface microlayer: Biology, chemistry and anthropogenic enrichment, Prog. Oceanogr., 11, 307-328, doi:10.1016/0079-6611(82)90001-5, 1982.

Harvey, G. W. and Burzell, L. A.: A simple microlayer method for small samples, Limnol. Oceanogr., 11, 608-614, 1972.

Helms, J. R., Stubbins, A., Ritchie, J. D., Minor, E. C., Kieber, D. J., and Mopper, K.: Absorption spectral slopes and slope ratios as indicators of molecular weight, source, and photobleaching of chromophoric dissolved organic matter, Limnol. Oceanogr., 53, 955-969, 2008.

Huguet, A., Vacher, L., Relexans, S., Saubusse, S., Froidefond, J. M., and Parlanti, E.: Properties of fluorescent dissolved organic matter in the Gironde Estuary, Org. Geochem., 40, 706-719, doi:10.1016/j.orggeochem.2009.03.002, 2009.

Ishii, S. K. L. and Boyer, T. H.: Behavior of Reoccurring PARAFAC Components in Fluorescent Dissolved Organic Matter in Natural and Engineered Systems: A Critical Review, Environ. Sci. Technol., 46, 2006-2017, doi:10.1021/es2043504, 2012.

Jørgensen, L., Stedmon, C. A., Kragh, T., Markager, S., Middelboe, M., and Søndergaard, M.: Global trends in the fluorescence characteristics and distribution of ma- rine dissolved organic matter, Mar. Chem., 126, 139-148, doi:10.1016/j.marchem.2011.05.002, 2011.

Kaiser, K. and Benner, R.: Biochemical composition and size distribution of organic matter at the Pacific and Atlantic time-series stations, Mar. Chem., 113, 63-77, doi:10.1016/j.marchem.2008.12.004, 2009.

Keeling, R. F., Körtzinger, A., and Gruber, N.: Ocean Deoxygenation in a Warming World, Annual Review of Marine Science, 2, 199-229, doi:10.1146/annurev.marine.010908.163855, 2010.

Kieber, D. J.: Photochemical production of biological substrates, in: The effects of UV radiation in the marine environment, edited by: De Mora, S., Demers, S., and Vernet, M., Cambridge Environmental Chemistry Series (No. 10), Cambridge University Press, 130-148, 2000.

Kieber, D. J., McDaniel, J., and Mopper, K.: Photochemical source of biological substrates in sea water: implications for carbon cycling, Nature, 341, 637-639, 1989.

Kuznetsova, M., Lee, C., and Aller, J.: Enrichment of amino acids in the sea surface microlayer at coastal and open ocean sites in the North Atlantic Ocean, Limnol. Oceanogr., 49, 1605-1619, 2004.

Lachkar, Z. and Gruber, N.: What controls biological production in coastal upwelling systems? Insights from a comparative modeling study, Biogeosciences, 8, 2961-2976, doi:10.5194/bg-82961-2011, 2011.

Lawaetz, A. J. and Stedmon, C. A.: Fluorescence Intensity Calibration Using the Raman Scatter Peak of Water, Appl. Spectrosc., 63, 936-940, doi:10.1366/000370209788964548, 2009.

Liss, P. S. and Duce, R. A.: The Sea Surface and Global Change, Cambridge University Press, 2005.

Liu, H. and Fang, H. H. P.: Characterization of electrostatic binding sites of extracellular polymers by linear programming analysis of titration data, Biotechnol. Bioeng., 80, 806-811, doi:10.1002/bit.10432, 2002.

Loginova, A. N., Borchard, C., Meyer, J., Hauss, H., Kiko, R., and Engel, A.: Effects of nitrate and phosphate supply on chromophoric and fluorescent dissolved organic matter in the Eastern Tropical North Atlantic: a mesocosm study, Biogeosciences, 12, 6897-6914, doi:10.5194/bg-12-6897-2015, 2015.

Loiselle, S., Vione, D., Minero, C., Maurino, V., Tognazzi, A., Dattilo, A. M., Rossi, C., and Bracchini, L.: Chemical and optical phototransformation of dissolved organic matter, Water Res., 46, 3197-3207, doi:10.1016/j.watres.2012.02.047, 2012.

Matrai, P. A., Tranvik, L., Leck, C., and Knulst, J. C.: Are high Arctic surface microlayers a potential source of aerosol organic precursors?, Mar. Chem., 108, 109-122, doi:10.1016/j.marchem.2007.11.001, 2008.

Miller, W. L. and Zepp, R. G.: Photochemical production of dissolved inorganic carbon from terrestrial organic matter: Significance to the oceanic organic carbon cycle, Geophys. Res. Lett., 22, 417-420, doi:10.1029/94gl03344, 1995.

Mopper, K. and Schultz, C. A.: Fluorescence as a possible tool for studying the nature and water column distribution of DOC components, Mar. Chem., 41, 229-238, doi:10.1016/03044203(93)90124-7, 1993.

Mopper, K., Kieber, D. J., and Stubbins, A.: Marine Photochemistry of Organic Matter: Processes and Impacts, in: Biogeochemistry of marine dissolved organic matter, Second Edn., edited by: Hansell, D. A. and Carlson, D. J., Academic Press - Elsevier, 390-450, doi:10.1016/B978-0-12-405940-5.00008-X, 2014. 
Morán, X. A. G., Alonso-Sáez, L., Nogueira, E. Ducklow, H. W., González, N. López-Urrutia, Á., Díaz-Pérez, L., Calvo-Díaz, A., Arandia-Gorostidi, N., and Huete-Stauffer, T. M.: More, smaller bacteria in response to ocean's warming?, P. R. Soc. B., 282, 20150371, doi:10.1098/rspb.2015.0371, 2015.

Mostofa, K. G., Liu, C.-Q., Yoshioka, T., Vione, D., Zhang, Y., and Sakugawa, H.: Fluorescent Dissolved Organic Matter in Natural Waters, in: Photobiogeochemistry of Organic Matter, edited by: Mostofa, K. M. G., Yoshioka, T., Mottaleb, A., and Vione, D., Environmental Science and Engineering, Springer, Berlin, Heidelberg, 429-559, 2013.

Muller-Karger, F. E., Varela, R., Thunell, R., Luerssen, R., Hu, C., and Walsh, J. J.: The importance of continental margins in the global carbon cycle, Geophys. Res. Lett., 32, L01602, doi:10.1029/2004GL021346, 2005.

Murphy, K. R., Stedmon, C. A., Waite, T. D., and Ruiz, G. M.: Distinguishing between terrestrial and autochthonous organic matter sources in marine environments using fluorescence spectroscopy, Mar. Chem., 108, 40-58, doi:10.1016/j.marchem.2007.10.003, 2008.

Murphy, K. R., Stedmon, C. A., Graeber, D., and Bro, R.: Fluorescence spectroscopy and multi-way techniques. PARAFAC, Anal. Methods, 5, 6557-6566, doi:10.1039/c3ay41160e, 2013.

Nelson, N. B. and Siegel, D. A.: The Global Distribution and Dynamics of Chromophoric Dissolved Organic Matter, Annual Review of Marine Science, 5, 447-476, doi:10.1146/annurevmarine-120710-100751, 2013.

Nieto-Cid, M., Álvarez-Salgado, X. A., Gago, J., and Pérez, F. F.: DOM fluorescence, a tracer for biogeochemical processes in a coastal upwelling system (NW Iberian Peninsula), Mar. Ecol.Prog. Ser., 297, 33-50, doi:10.3354/meps297033, 2005.

Ortega-Retuerta, E., Passow, U., Duarte, C. M., and Reche, I.: Effects of ultraviolet $\mathrm{B}$ radiation on (not so) transparent exopolymer particles, Biogeosciences, 6, 3071-3080, doi:10.5194/bg-63071-2009, 2009.

Paulmier, A. and Ruiz-Pino, D.: Oxygen minimum zones (OMZs) in the modern ocean, Prog. Oceanogr., 80, 113-128, doi:10.1016/j.pocean.2008.08.001, 2009.

Paulmier, A., Ruiz-Pino, D., and Garcon, V.: The oxygen minimum zone (OMZ) off Chile as intense source of $\mathrm{CO}_{2}$ and $\mathrm{N}_{2} \mathrm{O}$, Cont. Shelf Res., 28, 2746-2756, doi:10.1016/j.csr.2008.09.012, 2008.

Paulmier, A., Ruiz-Pino, D., and Garçon, V.: $\mathrm{CO}_{2}$ maximum in the oxygen minimum zone (OMZ), Biogeosciences, 8, 239-252, doi:10.5194/bg-8-239-2011, 2011.

Piontek, J., Händel, N., Langer, G., Wohlers, J., Riebesell, U., and Engel, A.: Effects of rising temperature on the formation and microbial degradation of marine diatom aggregates, Aquat. Microb. Ecol., 54, 305-318, 2009.

Riebesell, U., Kortzinger, A., and Oschlies, A.: Sensitivities of marine carbon fluxes to ocean change, P. Natl. Acad. Sci. USA, 106, 20602-20609, doi:10.1073/pnas.0813291106, 2009.

Rosenberg, R., Arntz, W. E., de Flores, E. C., Flores, L. A., Carbajal, G., Finger, I., and Tarazona, J.: Benthos biomass and oxygen deficiency in the upwelling system off Peru, J. Mar. Res., 41, 263-279, doi:10.1357/002224083788520153, 1983.

Santín, C., Yamashita, Y., Otero, X. L., Álvarez, M. Á., and Jaffé, R.: Characterizing humic substances from estuarine soils and sediments by excitation-emission matrix spectroscopy and parallel factor analysis, Biogeochemistry, 96, 131-147, doi:10.1007/s10533-009-9349-1, 2009.

Santos, A. L., Oliveira, V., Baptista, I., Henriques, I., Gomes, N. C., Almeida, A., Correia, A., and Cunha, A.: Effects of UV-B radiation on the structural and physiological diversity of bacterioneuston and bacterioplankton, Appl. Environ. Microb., 78, 2066-2069, doi:10.1128/aem.06344-11, 2012.

Schneider-Zapp, K., Salter, M. E., Mann, P. J., and Upstill-Goddard, R. C.: Technical Note: Comparison of storage strategies of sea surface microlayer samples, Biogeosciences, 10, 4927-4936, doi:10.5194/bg-10-4927-2013, 2013.

Senesi, N.: Molecular and quantitative aspects of the chemistry of fulvic acid and its interactions with metal ions and organic chemicals, Anal. Chim. Acta, 232, 77-106, doi:10.1016/S00032670(00)81226-X, 1990.

Senesi, N., Miano, T. M., Provenzano, M. R., and Brunetti, G.: Characterization, differentiation and classification of humic substances by fluorescence spectroscopy, Soil Sci., 152, 259-271, 1991.

Shick, J. M. and Dunlap, W. C.: Mycosporine-like Amino Acids and related Gadusols: Biosynthesis, Accumulation, and UVProtective Functions in Aquatic Organisms, Annu. Rev. Physiol., 64, 223-262, doi:10.1146/annurev.physiol.64.081501.155802, 2002.

Singh, S., D'Sa, E. J., and Swenson, E. M.: Chromophoric dissolved organic matter (CDOM) variability in Barataria Basin using excitation-emission matrix (EEM) fluorescence and parallel factor analysis (PARAFAC), Sci. Total Environ., 408, 32113222, doi:10.1016/j.scitotenv.2010.03.044, 2010.

Solomon, S., Qin, D., Manning, M., Chen, Z., Marquis, M., Averyt, K. B., Tignor, M., and Miller, H. L.: Climate Change 2007: The Physical Science Basis. Contribution of Working Group I to the Fourth Assessment Report of the Intergovernmental Panel on Climate Change, Cambridge University Press, Cambridge, United Kingdom and New York, NY, USA, 2007.

Stedmon, C. A. and Bro, R.: Characterizing dissolved organic matter fluorescence with parallel factor analysis: a tutorial, Limnol. Ocenogr.-Meth., 6, 572-579, 2008.

Stedmon, C. A. and Markager, S.: Resolving the variability in dissolved organic matter fluorescence in a temperate estuary and its catchment using PARAFAC analysis, Limnol. Oceanogr., 50, 686-697, doi:10.4319/lo.2005.50.2.0686, 2005a.

Stedmon, C. A. and Markager, S.: Tracing the production and degradation of autochthonous fractions of dissolved organic matter by fluorescence analysis, Limnol. Oceanogr., 50, 1415-1426, doi:10.4319/lo.2005.50.5.1415, 2005b.

Stedmon, C. A., Markager, S., Tranvik, L., Kronberg, L., Slätis, T., and Martinsen, W.: Photochemical production of ammonium and transformation of dissolved organic matter in the Baltic Sea, Mar. Chem., 104, 227-240, doi:10.1016/j.marchem.2006.11.005, 2007.

Stramma, L., Johnson, G. C., Sprintall, J., and Mohrholz, V.: Expanding Oxygen-Minimum Zones in the Tropical Oceans, Science, 320, 655-658, doi:10.1126/science.1153847, 2008.

Swan, C. M., Siegel, D. A., Nelson, N. B., Carlson, C. A., and Nasir, E.: Biogeochemical and hydrographic controls on chromophoric dissolved organic matter distribution in the Pacific Ocean, DeepSea Res. Pt. I, 56, 2175-2192, doi:10.1016/j.dsr.2009.09.002, 2009. 
Tilstone, G. H., Airs, R. L., Vicente, V. M., Widdicombe, C., and Llewellyn, C.: High concentrations of mycosporine-like amino acids and colored dissolved organic matter in the sea surface microlayer off the Iberian Peninsula, Limnol. Oceanogr., 55, 18351850, doi:10.4319/lo.2010.55.5.1835, 2010.

Weishaar, J. L., Aiken, G. R., Bergamaschi, B. A., Fram, M. S., Fujii, R., and Mopper, K.: Evaluation of Specific Ultraviolet Absorbance as an Indicator of the Chemical Composition and Reactivity of Dissolved Organic Carbon, Environ. Sci. Technol., 37, 4702-4708, doi:10.1021/es030360x, 2003.

Wurl, O. and Holmes, M.: The gelatinous nature of the sea-surface microlayer, Mar. Chem., 110, 89-97, doi:10.1016/j.marchem.2008.02.009, 2008.

Yamashita, Y. and Jaffé, R.: Characterizing the Interactions between Trace Metals and Dissolved Organic Matter Using ExcitationEmission Matrix and Parallel Factor Analysis, Environ. Sci. Technol., 42, 7374-7379, doi:10.1021/es801357h, 2008.

Yamashita, Y. and Tanoue, E.: Chemical characterization of proteinlike fluorophores in DOM in relation to aromatic amino acids, Mar. Chem., 82, 255-271, doi:10.1016/s0304-4203(03)00073-2, 2003.
Yamashita, Y., Cory, R. M., Nishioka, J., Kuma, K., Tanoue, E., and Jaffé, R.: Fluorescence characteristics of dissolved organic matter in the deep waters of the Okhotsk Sea and the northwestern North Pacific Ocean, Deep-Sea Res. Pt. II, 57, 1478-1485, doi:10.1016/j.dsr2.2010.02.016, 2010.

Zhang, J. and Yang, G.: Chemical properties of colored dissolved organic matter in the sea-surface microlayer and subsurface water of Jiaozhou Bay, China in autumn and winter, Acta Oceanol. Sin., 32, 26-39, doi:10.1007/s13131-013-0306-4, 2013.

Zhang, Z., Liu, L., Wu, Z., Li, J., and Ding, H.: Physicochemical Studies of the Sea Surface Microlayer: I. Thickness of the Sea Surface Microlayer and Its Experimental Determination, J. Colloid Interface Sci., 204, 294-299, doi:10.1006/jcis.1998.5538, 1998.

Zsolnay, A., Baigar, E., Jimenez, M., Steinweg, B., and Saccomandi, F.: Differentiating with fluorescence spectroscopy the sources of dissolved organic matter in soils subjected to drying, Chemosphere, 38, 45-50, doi:10.1016/S0045-6535(98)00166-0, 1999. 